Letras, Lima. 1977-79. (Nos. 86-87) 17-46.

\title{
El manierismo en la pintura colonial Latinoamericana*
}

FRANCISCO STASTNY

Hay una tendencia muy comprensible en los estudiosos que se han ocupado de la pintura colonial latinoamericana de recurrir al expediente de buscar explicaciones únicas para dar cuenta de la génesis y evolución de ese arte. Esas panaceas explicativas pasaron sucesivamente del concepto que el Nuevo Mundo no es sino un apéndice de la escuela española; a que todo el fenómeno americano puede aclararse en función del uso de grabados flamencos; y más recientemente, a la noción del manierismo.

Desde que M.S. Soría escribió que "el estilo resultante (en la pintura colonial) entre 1550 y 1750 es el manierismo", (1) la idea ganó rápida aceptación. En los últimos años se han multiplicado las referencias a ese fenómeno y ocasionalmente se encuentran comparaciones desconcertantes de obras producidas en América con pintores como Vasari, El Greco, el Rosso Fiorentino o el propio

- Este trabajo fue presentado al Coloquio Internacional de Oaxtepec sobre La Diáspora del Manierismo, organizado por el Instituto de Investigaciones Estéticas de la Universidad Autónoma de México, del 26 al 28 de julio de 1976. La versión que aquí se ofrece ha sufrido correciones, algunas addendas y una alteración en el orden de los capítulos.

** El estudio del arte del siglo XVI me fue accesible gracias a una beca de la Fundación John Simon Guggenheim, a la cual estoy reconocido por haberme facilitado una estadia en Europa con el propósito específico de investigar la obra de Mateo Pérez de Alesio. Fn torno a la figura de ese artista viajero he podido reconstruir las relaciones intercontinentales tejidas por el estilo de la Contra-Maniera tal como se explican en este ensayo.

(1) G. Kubler, M.S. Soria: Art and architecture in Spain, Portugal and their American dominions. 1500-1800. Pelican History of Art. Harmondsworth, 1959, 303. 
Miguel Angel. El desconcierto que producen esos acoplamientos proviene no sólo de una inmediata divergencia formal que se hace sentir, sino también de un enfoque distinto de propósitos. (2) Es al menos el caso de los ejemplos más extremos del manierismo italiano como Ponlormo, Rosso o Bronzino, frente, a los cuales no puede dejar de percibirse una diferencia abismal en comparación con el mundo artístico americano.

Sin duda el problema reside en el término "manierismo", que abarca con elasticidad una diversidad de corrientes en un nerícdo de casi cien años, durante los cuales se multiplicaron las búsquedas y los cuestionamientos. El uso indiscriminado de la palabra "manierismo" para designar el arte italiano entre 1520 y 1600 , tiene el inconveniente no sólo de encubrir la coexistencia de tendencias disímiles en el transcurso de esas décadas; sino también de teñir a todo el conjunto con los rasgos de algunas de sus formas más extremas ( 3 ).

El mundo de las formas artísticas se transforma, por lo común, lentamente $\mathrm{y}$ los nuevos modos de expresión se elaboran con la materia prima acumulada en la reserva de modelos y experiencias del pasado. Los artistas realizan con esas reservas, por medio de su actividad creadora, una contínua búsqueda formal para hallar el "tono justo" que coincida con el clima del pensamiento social de su tiempo. Los ligeros pero significativos reajustes formales que así se producen, han sido adecuadamente comparados a cambios en la sintaxis de un lenguaje que no altera su vocabulario (4). Ocasionalmente esas transformaciones alcanzan un clímax que conduce $a$ un reordenamiento formal profundo. Se reconoce, entonces, el nacimiento de un nuevo estilo. Un estudio más detenido de ese proceso descubriráo unaracción acumulativa anterior, que actúa como las aguas detenidas por un dique, antes

(2) Por eiemplo, en una obra como la de J. Mesa. T. Gisbert: Bitti, un pintor manierista en Sudamérica, La Paz, 1974, $(30,50,56,63,105$, etc.), se altera totalmente el sentido del arte contra-reformista y provinciano de Bitti, al desconocerse el significado de los movimientos artísticos italianos del ' 500 a los cuales estuvo relacionado. El pintor jesuita es presentado como un artista "manierista", que "añade espontaneidad" a las composiciones de Vasari (p. 38), y que estaría vinculado estilísticamente al Miguel Angel de la bóveda de la Capilla Sistina (pgs. 50, 63.). Véase notas $36-38$ y 44 .

(3) De modo parecido en la arquitectura se tiende a englobar bajo un mismo concepto estilístico el "furor arquitectónico" de Serlio, con el ánimo "regulador" de Vignola. Véase, por ejemplo, S. Sebastiān: Notas sobre la arquitectura manierista en Quito. BCIHE. No. 1, 1964, 114-115. Sin embargo lo que predomina en América son los elementos reguladores. Véase: E.W. Palm: El arte del Nuevo Mundo después de la conquista española, BCIHE, No. 4, Caracas, 1966, 49.

(4) S.J. Freedberg: Painting in Italy, 1500-1600. Pelican History of Art. Harmondsworth, 1971, 294. 
de que se produzca el desbordamiento. Esa acción acumulativa, o esos reajustes en la sintaxis, son el tema de este ensayo (5). .

\section{II}

No es en realidad ninguna novedad señalar que en el manierismo se distinguen diferentes etapas. Ya en la década de 1920 Walter Friedlönder publicó unos ensaryos en los cuales diferenció dos grandes facetas: la del manierismo o anti-clásica y la del anti-manierismo (6). Es, pues, una noción iniciada al menos hacemedio siglo, la que reconoce diversas fases en la pintura italioma del siglo XVI. No está demós, por eso, en insistir en que es preciso evitar la posición cómoda que induce a mirar desde América al arte italiono del '500 como una gran cantera indiscriminada de "manierismo". Es necesario precisar los conceptos. De otro modo el estudio de las fuentes en vez de contribuir a explicar los fenómenos artísticos de América, será motivo de una nueva confusión, tanto más grave cuanto que se presenta bajo la apariencia de una explicación histórica.

Los planteamientos que preocuparon a Friedländer fueron también tratados por otros autores como H. Voss, W. Weisbach, M. Dvorak y N. Pevsner. Y más recientemente S.J. Freedberg ha elaborado un excelente resumen de la cuestión en su libro sobre la pintura italiana del siglo XVI (7). Se deriva de esos trabajos que en el estilo manierista pueden distinguirse básicamente tres momentos. El inicial, que tuyo una fuerte tendencia experimental, anticlásica, y que se desarrolló en gran parte en Florencia. Lá maniera propiamente dicha, que ocupó el segundo tercio del siglo Y que implicó una reconciliación operativa con los cónones clá. sicos del alto Renacimiento. Y finalmente el período tardío, que hasta los últimos años del siglo repitió fórmulas de la maniera, pero con una nerviosidad cada vez moryor y con una mayor amplitud de movimiento.

(5) Tal vez se encuentre un simil más familiar en el paso casi imperceptible entre el arte barroco y el "rococó". También en ese caso se trató de un reordenamiento con nuevos propósitos de un vocabulario existente.

(6) Friedlander distingue, además, en la primera fase dos momentos: el del anti-clasicismo y el de la "maniera" propiamente dicha. $\mathrm{W}$. Friedlander: Mannerism and Anti-Mannerism in Italian Painting, Schoken Books, New York, 1965.

(7) H. Voss: Die Malerel der Spätrenalssance in Rom und Florenz, 2 vols. Berlin, 1929; W. Weisbach: Der Manierismus, Zeitschrift fur bildende Kunst. Vol. XXX, 1919: M. Dvorak: Uber Greeo und der Manlerismus, Wiener Jahrbuch für Kunstgeschichte, 1921, 22; N. Pevsner: Gegenreformation und Manierismus, Repertorium für Kunstvissenschaft, XIVI, 1925; S. J. Freedberg, Op. cit. 
El período inicial desarrolló aquellas expresiones de exacerbada extravagancia, que a veces se atribuyen erróneamente a todo el estilo. Lo que Rosso y Pontormo realizaron en la tercera década del siglo obedeció a reacciones muy personales a la nueva situación cultural, religiosa y política del momento y no tuvo continuidad posterior. Sus pinturas rompieron con la concepción espacial de los grandes maestros de los primeros veinte años del siglo. Destruyeron la equilibrada relación de los protagonistas de sus composiciones con el ambiente que los circunda. Sus figuras aparecen sobrepuestas y entretejidas en un esquema ornamental que se desarrolla sólo en superficie. Y por distorsión, gesticulación 0 bizarría de actitud describen un inédito mundo de frialdad emocional que a menudo deja traslucir angustia y dolor.

Hacia finales de la cuarta década surgió la modalidad que los antiguos teóricos del arte reconocieron como maniera. Por acción conjunta de los artistas romanos y de los florenrinos, se desarrolló, así, un lenguaje formalizado, que buscó una reconciliación con los modelos de los grandes maestros y que perdió el extremo personalismo de la primera etapa. La "alta maniera", como la denomina Freedberg, poseía una exacerbada conciencia del valor del arte como pura expresión estética. La grazia y una elegancia artificial fueron da razón de existir de sus figuras. La expresión de contenidos emotivos estuvo limitada al mínimo. Los sentimientos fueron reprimidos. Los personajes, inspirados muchas veces en la escultura marmórea tienen la apariencia y la consistencia de la piedra. La composición de sus cuadros está concebida en términos de agitadas superficies ornamentales y se desarrolla en profundidadotan sóloapor superposición de estratos relacionados entre sí por esquemas similares que se repiten como las reverbaciones de un eco. Bronzino, Salviati, Jacopino del Conte, Vasari, son algunos de los exponentes más conocidos de esta modalidad. El que practicaron fue un arte refinado, creado para conocedores, en el que combinaron y recombinaron elementos del Alto Renacimiento y de la primera maniera haciendo alarde de creciente ingeniosidad en el uso frecuente de paradojas gráficas que son interpoladas en las composiciones como citas eruditas intercaladas intencionadamnte en contextos inapropiados.

Más aún, fue un arte que no pudo plasmar una expresión religiosa directa y convincente. Los temas cristianos son presentados en un ambiente de abstracción simbólica y en un contexto formal refinado y esteticista, que sólo fue apreciable para espectadores sumamente cultos, capaces de sintetizar por sus propios medios intelectuales un mensaje religioso implícito (8).

(8) Véase un resumen de la evolución de la "maniera" en S.J. Freedberg, Op. cit., 114-16; y el problema de la expresión de contenidos religiosos en Ibidem, 290. 
El epígono de este estilo, que se descrrolló entre 1570 y 1590 , mantuvo básicamente la misma actitud formalista en artistas como Jacopo Zucchi, Raffaellino de Reggio, N. Circignamo o el Caballero de Arpino.

Bien inútll sería nuestra búsqueda si quisiéramos hallar relaciones directas entre esos artistas ifaliamos vinculados a la maniera con los pintores activos en América en la misma época, como Bitti, Alesio, Echave Orio o Pereyns. Todo en ellos, con excepción de alguna que otra fórmula, es diferente.

Pero simultáneamente en Italia se desarrollaron, desde me diados de siglo, otros experimentos que corrieron paralelos al auge de la maniera. A menudo los mismos artistas se exprescron en una u otra modalidad, según los requerimientos de los patrones para los cuales trabajaban. La novedad de esa nueva variante, como era de esperarse, provino de las exigencias religiosas señaladas por el ambiente en que se desarrolló el Conclio de Trento (15451563). Su actitud tue opuesta a las convenciones de los artistas anteriormente descritos y por eso se la conoce con el nombre de la contramaniera. Pero.nsu oposición es de propósito, más que de idioma. Es, como señalamos anteriormente, un reordenamiento del vocabulario manierista en una nueva sintaxis. Y en cierta manera no es sino la otra cara de la medalla manierista, aplicada a diferentes intenciones. La raíz del movimiento se encuentra en el. Juicio y en la Capilla Paolina de Miguel Angel, donde, conmovido por una nueva crisis religiosa, el genial florentino se alejó intencionalmente del concepto de la grazia, para crear una humonidad sufriente y composiciones de lectura clara. Desde entonces se hizo cada vez más apremiante la doctrina de que el arte debe ilustrar los contonidos religiosos y ser fácilmente inteligible:s Las ideas de Mitguel Angel fueron retomadas por M. Venusti y Daniel de Volterra; y más tarde seguiróm por esa ruta Jacopino del Conte, Siciolante, G. Muziano y Federico Zuccari.

Todavía más avanzado en sus experimentos fue un grupo de pintores coetáneos que Freedberg llama los "reformadores florentinos" (9). A diferencia de los contra-monieristas romanos, estos arlistas buscaron inspiración en el Alto Renacimiento, en vez de referirse a los creadores de la primera maniera. Sus obras son más contundentes en la búsqueda de una descripción naturalista de la realidad, en la claridad compositiva y en la transmistón diáfana del contenido. Es el caso de Santi di Tito, Jacopo Chimenti da Empoli, Il Cigoli e Il Passignano.

La última consecuencia de estas transformaciones, antes de la ruptura del dique por el naturalismo irresistible de Caravaggio y de la plenitud emocional de los Carracci, será una transforma-

(g) S.J. Freedberg, Op. cit., 419, 238 ss. 
ción formal cargada de arcaismos, que se conoce como la anti-maneira. A diferencia de la contra-maneira, esta modalidad implica una abierta rebelión contra los principios de la maniera. Ya no sólo se busca un arte que sea de lectura clara, sino un estilo religioso que promueva los nuevos principios de la Iglesia y que guste al simple hombre del pueblo. Es así que se produce una auténtica ruptura con los propósitos anteriores que, en una forma $\mathrm{u}$ otra, habían sido siempre dirigidos a una élite extremadamente refinada en sus gustos estéticos. Por primera vez surge entonces en Europa lo que Federico Zeri denomina el "arte sacra", o sea un estilo de propaganda religiosa, un arte misionero. Ningún artista ejemplifica mejor esta tendencia que Scipione Pulzone de Gaeta en cuyas obras más características se reunen todos los rasgos del estilo: un naturalismo minucioso, una composición basada en Rafael, pero estructurada con una timidez calculada en su arcaismo, y la expresión de sentimientos piadosos y "honestos". Pulzone no estuvo solo en el descubrimiento de esa modalidad. Su esfuerzo fue precedido y dirigido intelectualmente por $G$. Valeriano, seguidor de la tradición religiosa de Miguel Angel por conducto de Muziano. Valeriano fue miembro de la Compañía de Jesús, en cuyo clima intelectual y en cuya iglesia de Il Gesú eclosionaron por primera vez estos experimentos para hallar un nuevo arte de ilustración cristiana (10).

Es el propósito de este trabajo examinar brevemente cómo las variantes estilísticas descritas repercutieron en América; así como tomar en consideración los factores geográficos en lo que se refiere a los lugares de origen y de recepción de las influencias que jugaron un papel activo en las relaciones entre el Antiguo y el Nuevo Mundo; y finalmente mencionar someramente los resultados perceptibles de estas influencias en las escuelas locales.

\section{III}

Así como se ha reconocido que existe una clara distinción entre los virreinatos de Nueva España y del Perú en lo que se refiere al origen estilístico de los prototipos arquitectónicos que los influenciaron, así también en la pintura sucede un fenómeno parecido. La tierra mexicana, conquistada primero y geográficamente más cercana a la Metrópoli, fue más susceptible a las corrientes hisoanas $\mathrm{y}$, en el caso de la pintura, a los ejemplos flamencos, que eran tan vigorosos en la propia Península. El virreinato pe-

(10) Acerca de la "anti-Maniera" y el "arte sacra" véase sobre todo F. Zeri: Pittura e Controriforma, Torino, 1957. Acerca de los jesuitas y G. Valeriano en su acción sobre el arte de la época: $R$. Wittkower, I. Jaffé: Baroque art: the Jesuit contribution. New York, 1972. 
ruano, en cambio, recibió prioritariamente influencias no-ibéricas: flamencas en la arquitectura y netamente italianas en la pintura.

Es necesario aclarar desde el inicio que en ambos casos se trata de influencias predominantes y no exclusivas. Italia y Flandes fueron los dos grandes centros creativos del lenguaje pictórico en el siglo XVI. Prácticamente en ningún lugar puede hablarse de la presencia aislada de tan sólo una de esas corrientes. La segunda mitad del siglo presenció en los centros europeos una progresiva y creciente hibridación de tendencias. El arte italiono utilizó y adquirió rasgos flamencos. Multitud de pintores de Flandes hicieron el viaje al sur para aprender y trabajar. Y aunque Van Mander se queje de que los utilizaran solamente para pintar grutescos y fondos de paisajes (11), es un hecho que Italia asimiló rápidamente, primero, los principios de representación de la naturaleza de artistas como los hermanos Bril; y luego, de otros como D. Calvaert y Peter Candid, la minuciosa observación de interiores $\mathrm{y}$ de detalles texturales tan frecuentemente utilizados on las etapas de la contra-maniera y de la anti-maniera.

El movimiento inverso fue aún más acentuado. Desde tiempos muy tempranos los artistas flamencos del siglo XVI cayeron bajo la fascinación del Renacimiento italiano y lo imitaron. Este cosmopolitismo fue particularmente cierto en el arte religioso contrarreformista que buscá una forma de expresión adecuada a sus necesidades recurriendo a elementos de muy diversas fuentes (12).

En América, una comparación de la pintura del virreinato peruano y del mexicano, descubrirá una hibridación semejante. Al lado de la predominancia italiana, existe una considerable intromisión de elementos flamencos en América del Sur. Estos se hacen presentes, desde el origen, en la propia obra de Bitti. O por intermedio de ciertos grabados de éxito utilizados desde época temprana en todo el Continente, como la Adoración de los Reyes, de

(11) "Porque los italianos creen siempre que nosotros sólo tenemos talento para esos trabajos (de paisajes y grutescos), mientras que ellos lo tienen para las figuras". C. Van Mander: Den grondt der edel Schilder-const, Harlem, 1604, La Haya, 1916, I, 46.

En la 2a. ed. 1618, (Amsterdam), aparece la biografía por autor anónimo de Van Mander: "Hier is op niew bygevoecht het leven des ßutheurs", donde se dice que pintó "grutescos" con habilidad. Véase: M. Vaes. Le séjour de Carel van Mander en Italie. 1573-1577. Hommage à Dom U. Berlière. Bruselas, 1931, Apéndice I, 240 y 233-235, 236-237.

(12) Este internacionalismo es muy notorio en el estilo de la anti-maniera de Scipione Pulzone quien incorpora muchos elementos arcaizantes de la pintura flamenca (por ejemplo en la Piedad de New York, tan vinculada a Henri van den Broeck y reproducida en F. Zeri: (1p. cit., fig. 90); y cuyas obras posteriormente a su vez servirán de modelos a los flamencos romanistas como $\mathrm{F}$. Van de Kasteele y Martin de Vos. Véase: Dipinti Fiammenghi di Collexioni Romane, Roma, 1966, fig. 19; Musée Royal des Beaux Arts d'Anvers. Recueil de 200 Photogrames. Anvers, 1924, 152. 
1581, de Martin de Vos, copiada por Gregorio Gamarra (Fig 1), en la Paz, por el llamado Maestro de Pujiura, en el Cusco, y por Simón Perines (Fig. 2), en Huejotzingo (13).

De igual modo, es imposible dejar de percibir una contínua presencia italiana en las obras de los pintores españoles o flamencos activos en Nueva España (14).

No obstante, la predominancia del factor hispano-flamenco en el Norte y de Italia en el Sur del Continente, tendrán una repercusión profunda en el desarrollo ulterior de cada una de las escuelas de esas regiones, cuyas unidades de expresión estilística, no por poco estudiadas, dejan de ser una realidad claramente patente.

\section{IV}

Tal vez antes de proseguir deba volverse la mirada hacia el problema más fundamental de los orígenes. Antes de interrogarnos qué sucedió en relación con el manierismo, debemos plantearnos una pregunta más básica. ¿Qué ocurrió en América en relaciór al Renacimiento? $O$ para decirlo más francamente, ¿por qué, si el período cronológico es coincidente, no existen expresiones propiamente renacentistas en el Nuevo Mundo? Los numerosos murales que se conservan en los conventos de las órdenes religiosas en Nueva España, son un magnífico campo de estudio. En esa ornamentación se descubren a menudo frisos derivados de grabados italianos y germánicos del tardío siglo XV o del inicio del XVI; las composiciones de algunas de las escenas representadas también provienen de orígenes renacentistas. Pero no por eso pueden juzgarse a esas obras como productos del Renacimiento. Quienes ejecutaron los murales fueron artistas indios, Yápidamente asimilados a las costumbres occidentales, o artistas europeos menores. Muy lejos de percibirse en ellos la clara comprensión del mundo de la geometría euclidiana y la equilibrada integración de objetos y personajes en un universo de proporción humana, lo que está presente es el trazo cuidadoso y desplazado en superficie de dibujantes para quienes el plano del muro es impenetrable y para quienes

(13) Este ejemplo sirve simultáneamente para recordar la hibridación de las tendencias en su lugar de origen, ya que Martin de Vos fue uno de los más italianizados de los "romanistas" flamencos. D. Angulo I.: Pereyns y Martin de Vos: E1 retablo de Hueiotzingo, AIAA, 2, 194925.

(14) Por ejemplo, la observación de M.S. Soria de que Baltasar Echave Orio pudo haber estudiado en Florencia con artistas como Santi de Tito y Ligozzi (G. Kubler, M.S. Soria; Op. cit., 307), se ve confirmada por una comparación de la Visitación de Echave (Pinacoteca Virreinal, México) con la obra de J. Zucchi: La minería aurifera (Studiolo, PalazzoVecchio, Florencia), donde se encuentra la misma manera de tratar los drapeados, de solucionar la estructura del paisaje y hasta la misma forma de sombreros. W. Vitzthum: Lo Studiolo di Francesco I a Firenze, Milán, 1969, lám. 46. 
la anatomía de las figuras tiende imperceptiblemente a revertir a los cónones elementales de la geometriu. Los lienzos de Juan Gerson, el pintor indio de Tecamachalco, también ilustran perfectamente esta situación. Si se buscaran en el resto del continente expresiones parecidas, se encontrarán, en el mejor de los casos, soluciones igualmente alejadas de los ideales albertinianos. Más tardía, la Casa de Vargas, en Tunja, es otro ejemplo claro. En vez de reflejar una filiación vinculada al Renacimiento estas obras, como las bóvedas de nervadura que recubren a muchas de ellas, crean la impresión de pertenecer al mundo medieval, rígidas en su composición, geometrizadas en su estructura y profundamente comprometidas con el simbolismo de un contenido trascendente (15).

No seró necesario insistir en el hecho evidente de que el Renacimiento fue un fenómeno cultural demasiado complejo para que haya podido ser reducido a una simple combinación de reglas aplicables en América como un recetario de decoración. Sin la estructura del pensamiento filosófico y científico que renovó totalmente la visión del mundo y la imagen que el hombre tenía de su posición en el universo, como sucedió en Europa en el siglo XV, no pudo darse un estilo artístico que reflejara precisamente esas realidades intelectuales. "Lo más importante es comprender -escribió Pierre Francastel-que ninguna representación plástica del espacio puede estar divorciado de su contexto de valores sociales e intelectuales... La transición de la Edad Media al Renacimiento se produjo cuando empezó a desarrollarse la filosofía natural" (16).

Ahora bien, la situación social en América en el siglo XVI era totalmente diferente a la que reinaba en la Italia renacentista. Sin excluir la existencia de griupos de élitesfamiliarizados con las ideas humanistas más avanzadas de su tiempo, el ambiente en que se desenvolvió la creación artística fue muy distinto (17). El

(15) M. Toussaint: Pintura Colonial en México, México, 1965, 38 ss.; $X$. Moyssén: Tecamachalco y el pintor indigena Juan Gersón. AIIE, No. 33, 1964; M. S. Soria: La pintura del Siglo XVI en Sudamérica, Buenos Aires, 1956, 15 ss.

(16) P. Francastel: Destruction d'un espace plastique. En: Formes de l'Art, Formes de l'Esprit, Paris, 1951, 147.

(17) Acerca de la existencia de un arte de élite (manierista) en las ciudades de México, en oposición a las expresiones conventuales (platerescas) del campo, véase J.A. Manrique: Reflexión sobre el Manierismo en México, AIIE, No. 40,1971, 28 ss. Es necesario recordar, sin embargo, que como correctamente lo observa Manrique (p. 53), los grupos de la élite están sobre todo inspirados por el espiritu de la Contrareforma $\mathrm{y}$, por consiguiente, su expresión artística se realizó en el estilo de la contra-maniera. Lo que eso implica en cuanto a la diferencia de "tono" emocional implícito en ese estilo en comparación con la 'maniera' o la "alta-maniera", es más claramente perceptible en la pintura de la época que en la arquitectura, cuyas formas abstractas se prestan menos al análisis del contenido ideológico que los del lenguaje pictórico. 
factor de las grandes masas de población nativa cuya incorporación al sistema cristiano era urgente, condujo a que la iglesia revirtiera a soluciones y actitudes equiparables a la Edad Media europea (18). Es de tomarse en cuenta que el núcleo principal de inmigrantes españoles, a su vez, estaba más apegado a las nociones e ideales del mundo medieval ptolomeico que a las doctrinas más adelantadas de sus días. Un personaje como Henrico Martínez, cuya obra astrológica Repertorio de los tiempos se usó con gran éxito hasta el siglo XVIII, es un ejemplo muy significativo de estas formas de pensamiento pre-renacentista generalizadas en el Nuevo Mundo (19). Es, pues, normal, dentro de la naturaleza de la situación, que no pueda hablarse de Renacimiento en el sentido clásico o pré-clásico del término.

Si no hubo en la primera mitad del siglo creaciones propiamente renacentistas, por estar la expresión plásstica dirigida a un sector de la población para la cual ese estilo no hubiera tenido sentido, con mayor razón era totalmente improbable que se produjeran pinturas en el estilo de la primera o de la alta maniera. Formas de expresión extremadamente rebuscadas y cultas, hechas para ser apreciadas por una élile de conocedores sofisticados y compuestas en "conirapunto" a las grandes obras del Alto Renacimiento, las pinturas manieristas simplemente no tenían cabida en el horizonte americano. La frialdad emocional, la sensualidad rebuscada, el encubrimiento simbólico del contenido, la extrema complejidad formal reflejada en la preferencia por la figura serpentinata (20) (Fig. 3) y por composiciones espaciales plagadas de paradojas, son rasgos de las obras manieristas que las hubieran hecho no sólo incomprensib?es para la gran masa de la población americana, sino que hubierahssidd consideradas abbiertamente reprobables por las autoridades eclesiásticas (21).

En cambio, a mediados de siglo surgió en Italia, como ya se ha mencionado, un arte nuevo derivado de las últimas creaciones de Miguel Angel en la Capilla Paolina y que se planteó el problema de la pintura ya no en términos puramente estéticos, sino en

(18) E.W. Palm, Op. cit., 39-40.

(19) A. López Austin: Henrico Martinez. La inclusión de Nueva España en la cosmología medieval. Museo Nacional de Antropología, México, 1971. F. de la Maza: Enrico Martínez Cosmógrafo e impresor de Nueva España. México, 1943.

(20) Acerca de la figura serpentinata, véase el útil recuento de J. Shearman: Mannerism, Penguin Books, 1967, 81-91.

(21) La reacción contra el desnudo y los excesos de la maniera por parte de la iglesia empezó en 1559 cuando Pablo IV mandó que Daniel de Volterra cubra los desnudos del Juicin de Miguel Angel: y encontró su sanción en las conclusiones del Concilio de Trento (1563). E. Male: L'Art religieux de la fin du XVI siècle, du XVII siècle, et du XVIII siècle. Paris, 1951, Cap. I. 
relación a las nuevas exigencias religiosas que preocuparon a los hombres de la época. La contra-maniera fue esa nueva respuesta a los retos del arte y de la religión. Y fue fundamentalmente una modalidad cuyo neo-clasicismo, cuya claridad reglamentada la adaptaban idealmente a una función ditusora dentro y fuera de Europa (22). Fue ése el estilo que, con la participación de los sectores más cultos de la sociedad, será implantado a partir de 1560-75 en toda la América hispana.

Maniera y contra-maniera fueron variaciones dentro de un estilo que se produjeron simultáneamente en Italia. A menudo se encuentron artistas que trabajaron en ambas 'modalidades según el propósito de la obra. Y no siempre se respetó la división que podría parecer lógica: la de que se usara la maniera para los temas profanos y la contra-maniera para las obras religiosas (23).

De tal modo, los cambios de propósitos en las pinturas emprendidas a partir de la sexta década, indicaron claramente cambios en las soluciones formales. Mientras más se alejó el artista de las ambigüedades del sentimiento manierista, más varió su forma de enfocar la estructura de sus obras en el sentido de la contra-maniera. Existe un ejemplo muy claro en el cual se observa la aplicación de esta situación a la realiáad americana, en el caso del pintor Angelino Medoro, de quien se conocen obras producidas en Espa-

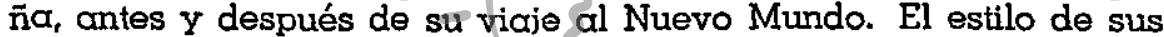
pinturas en uno y otro Continente no podía ser más distinto. Su Flagelación de (rists (Fig. 4), de 1586, en Sevilla, está claramente vinculada al manierismo florentno del grupo de artistas que trabajó en el Studiolo del Palazzo Vecchio. Refinada en el diseño, extravagante en la vestimenta de los soldados, toda la composición 'con su huyente perspectiva carquitectonica parece una fría representación teatral en la cual la grazia y elegante posición de las figuras es más importante que la veracidad de la escena. Todo lo contrario es cierto de las obras que pintó dos o tres años más tarde en Tunja, al punto de que cabría dudar que sean de la misma mano, si no se tuviera conocimiento del mecanismo que produjo esa profunda transformación formal (Fig., 5).

Antes aún, en Europa misma sucedió un caso paradigmático que señala en el mismo sentido. Cuando Mateo Pérez de Alesio viajó de Roma a Malta, en 1576, la transformación que se operó en su obra tuvo el mismo significado. Del gigantismo miguelange. lino de los Profetas del Oratorio del Gonfalone (Fig. 6), pasó sin tran.

(22) S.J. Freedberg: Op. cit., 293-4, 328 ss.

(23) Acerca de las aparentes contradicciones en el uso de la maniera y la contra-maniera en obras profanas y religiosas producidas en las grandes decoraciones murales emprendidas casi simultáneamente en el ámbito romano entre 1570-80, en Caprarola, Oratorio del Gonfalone y Oratorio del Crocefisso di S. Marcello, véase S.J. Freedberg: Op. cit. 443-4. 
sición a una mesura sorprendente en el Bautizo (Fig. 7) de la co-catedral de Valleta (24). Exactamente en los mismos años en que Alesio pintó en Malta, B. Bitti inició, bajo el mismo signo, su obra limeña (1575- 1583); y poco antes Simón Pereyns había llegado a México, donde en el Altar del Perdón (1568) (Fig. 8 y 9) se expresará en un estilo similar.

De modo que el fenómeno americano, muy lejos de ser una excepción, se inscribe perfectamente en la lógica de un movimiento artístico común a todo el ámbito de influencia de una iglesia comprometida con la lucha contrarreformista, dentro y fuera de Europa. La contra-maniera y más tarde la anti-maniera son las dos modalidades de una búsqueda sincera y sistemática por superar las limitaciones del alto manierismo y de lograr una expresión sin ambigüedades del sentimiento religioso. Desde la situaciór. privilegiada de nuestro mirador histórico, sabemos que esas experiencias serían estériles y que mientras no se produjera una liberación total de las formas y del lenguaje alegórico y que se superase el recuerdo obsesionante del clasicismo, esos experimentos no lograrían su cometido.

Todo lo contrario de un fenómeno marginal, la contra-maniera y la anti-maniera estuvieron enclavadas en los dos principales centros creativos de Italia, en Roma y Florencia; y de allí pasaron a todas las naciones católicas de Europa. En España, como en el Nuevo Mundo, su influencia se hizo sentir con vigor. Las obras de un artista como Pulzone de Gaeta fueron muy difundidas en España y aún quedan claros vestigios de esa popularidad. En la Catedral de Sevilla hay, por ejemplo, uno versión de su Calvario de Santa María in Vallicella (25). Y cuando José Antolínez, ya en pleno siglo XVII, "representó á un Corredor de cuadros, la pintura que ofrece el personaje no es otra que una repetición de la Virgen

(24) El drama de la auto-destrucción de sus frescos en el Oratorio del Gonfalone, que ocasionó la huída de Alesio a Malta tal como la raarran C. Van Mander y Sandrart, problablemente fue motivado precisamente por esa indecisión entre dos modalidades estilisticas. En todo caso, las obras piadosas que pintó para los Caballeros de San Juan no tienen iinguna relación con sus grandilocuentes composiciones de la Capilla istina y del Gonfalone. Véase: C. Van Mander: Het Shöldcrboeck, Harem. 1604. 194; J. von Sandrart: Teutsche Akademie der edlen Bau-Bild und Mahleren Künste, Nurenberg, 1665, Cap. XX; K. Oberhuber: Jacop Bertoia in Oratorium von S. Lucia del Gonfalone in Rome, Römische Historische Mitteilungen, 1958-59, Koln, 1960, 239-254; A. Molfino: L'Oratorio del Gonfalone, Roma, 1964, lám. IV, figs. 18-19. E. Sammut: The Co-Cathedral of St. John, Malta, 1967, fig, 56, 58.

(25) El cuadro está inédito y se conserva en la parte alta de la $\mathrm{Ca}$ pilla de S. Andrés (la. después de la Sacristía). Pulzone, artista antimanierista por excelencia, fue el iniciador de la pintura piadosa que Zeri llamó "el arte senza tempo". F. Zeri: Op. cit.; S.J. Freedberg: Op. cit., 509, No. 8. 
de la Rosa (Fig. 15), del artista gaetano (26). Esa composición tan representativa de la anti-maniera fue muy popular en España. Igualmente lo fue en el Perú, adonde fue introducida y difundida ampliamente por Alesio; y también en México se conserva un ejemplar en el Museo de la Academia (27).

Se ha dicho con razón de la modalidad herreriana -que equivale a una forma de contra-maniera arquitectónica- que representó un estilo imperial español de carácter universal, el cual otorgó uniformidad a los edificios hispánicos en oposición a la diversidad de tendencias regionales (28). De modo parecido, en pintura, la contra-maniera adquirió a partir de la década de 1580 un parecido matiz oficial, al ser el estilo en que Tibaldi, Cambiaso y Zuccaro decoraron el Escorial. Es cierto que Felipe II, con muY buen criterio artístico, aspiró originalmente decorar su monumento con pinturas de Tiziano y que no arreció la sequedad clasicista de Federico Zuccaro. Pero Tibaldi y Cambiaso pudieron satisfacer su gusto por un arte religioso y didácttco (29). Conociendo la obra bolognesa del primero en el Palacio Poggi, puede sorprender su drástico abandono de la maneira en España, pero esa transformación corresponde a las necesidades de su tiempo y cae perfectamente dentro del esquema que ya hemos señalado en otros artistas (30). La contra-maniera tendrá desde entonces, en la Península como en el nuevo Mundo, el prestigio de una forma de expresión oficializada de valor universal.

\section{Bibliotec $\mathbf{Y}$ de Letras}

En la América meridfonal, en periodo que nos incumbe examtnar contó con un número de centros regionales en actividad: Lima, Tunja, Bogotá, Quito, Cuzco, La Paz, Potosí son los principales. A medida que transcurrió el siglo XVII, los rasgos individuales de cada uno de ellos se fue acentuando. Pero en la época anterior a 1640 , esa situación no se había definido y más bien puede reconocerse una nuclearización marcada, cuyo epicentro fue Lima y

\footnotetext{
(26) A. Pérez Sánchez, Archivo Español de Arte, No. 135, Madrid, $1961,276$.

(27) F. Stastny: Pérez de Alesio y la pintura del siglo XVI. AIAA, No. 22, 1969, 7; E. Gual: Museo de San Carlos. México. 1968, 13. Véase también pg. 36 de este trabajo acerca de la difusión americana de un prototipo de Virgen Inmaculada compartido con S. Pulzone. 1949,8

(28) E.W. Palm: Estilo y época en el arte colonial. AIAA, No. 2,

(29) D. Angulo I.: La Pintura del Renacimiento. Ars Hispaniae, Nadrid, 1954, 257 ss.

(30) S. J. Freedberg: Op. cit., 392-393.
} 
desde el cual irradió una influencia determinante hacia el Norte y hacia el Sur (31).

En las primercis décadas posteriores a la conquista reinó en el Virreinato Peruano un arte ingenuo derivado principalmente de modelos hispano-flamencos gotizantes muy parecidos a los que xun estaban en uso en las regiones más provincianas de Andalucía. Una buena idea de ese estilo la da una tabla de la Virgen de Rocamador con San Telmo y San Cristóbal (Colección particular, Lima), que llegó al Perú indudablemente con una de las naves que hicieron el viaje al Nuevo Mundo (32). Pero este panorama hubo de cambiar radicalmente en 1575 con la llegada del primer artista italiano. Desde ese momento, por 60 ó 70 años, la presencia de Italia fue decisiva y excluyente. Por cierto que no faltó la hibridación con factores flamencos provenientes de la propia Italia y de estampas; pero no se hicieron presentes artistas flamencos sino en forma muy marginal (33). Al lado de los pintores italianos, son frecuentes los nombres de artistas españoles aue figuran en los documentos de la época. Lamentablemente la proporción de obras identificadas en relación a los numerosos patronímicos que aparecen en los archivos, es mínima. De una decena de artistas italianos que trabajaron en Lima, sólo hay obras identificadas con certeza de tres de ellos (34).

(31) Acerca del ambiente artístico limeño ca. 1590 y la influencia que ejerce la capital del Virreinato, tanto sobre el Cuzco, como su proyección hacia el Norte, sobre todo-en Quito, véase F. Stastny: Op. cit., 1969.

(32) Ambos santos otorgan protección alos viajeros y las naves que hacian la peligrosa trayesía desde España debían llevar numerosas pinturas parecidas." Es extraño que tan pocas se conserven. San Cristóbal es ampliamente conocido por la protección que otorga contra la muerte súbita y por ser el patrón de los viajeros. Véase L. Réau: Iconographie de l'Art Chretien. Paris, 1958, III, 306.

Una representación semejante de San Telmo con una nave sobre el hombro se encuentra en una pintura atribuída por D. Angulo a Vasco de Pereira, que representa la Virgen con Niño, los Reyes Magos y varios santos. (Col. Cepeda Palma del Condado). Véase: D. Angulo I., Op. cit., fig. 337

(33) De la obra del pintor flamenco Fray Pedro Gosseal, co-fundador del Convento de San Francisco en Quito (1535), o de sus alumnos indígenas, no quedan huellas. En Córdoba y Potosí trabajaron un flamenco, Rodrigo Saz (act. 1601-23), y un danés, Juan Bautista Daniel (act. en Córdoba en 1613). Este último, por lo demás, deriva de modelos italianos (M. Venusti basado en Miguel Angel) y no de la "maniera" sensual de B. Spranger como afirman J. Mesa y T. Gisbert: El pintor Juan Bautista Daniel, AIAA, No. 13, Buenos Aires, 1960, 91 ss.

(34) Bernardo Bitti, Mateo Pérez de Alesio y Angelino Medoro. Para el período en general véase: M.S. Soria: La pintura del Siglo XVI en Stzlamérica. Buenos Aires, 1956; E. Harth-Terré y A. Márquez Abanto: Pintores y pinturas en Lima Virreinal, Revista del Archivo Nacional, T. 27, Lima, 1964; J. Mesa y T. Gisbrt: El pintor Jaramillo y el 
En el Virreinato del Perú, como en los otros centros americanos, la pintura toma desde el inicio de este período un matiz claramente contra-manierista. En el caso de dos de los pintores, son conocidas sus obras europeas anteriores al viaje a América y la transformación operada en ellos es evidente, según lo hemos señalado anteriormente (35).

En lo que se refiere a Bernardo Bitt, que fue el primero en desembarcar en la costa peruana, probablemente no sufrió ese cambio inicial. El mismo fue hermano jesuita y estaba sin duda compenetrado en el ánimo del arte que su Companía deseaba transmitir (36). Mucho más tarde, al enterarse de las últimas novedades del arte anti-manierista propugnado por su Orden, se esforzará por incorporar esta nueva modalidad en sus obras (37). Durante su estada de poco más de un año en España pintó una Virgen, que no ha sido identificada todavía, y pudo haber conocido $\mathrm{y}$ haber sido influenciado por Giuseppe Valeriano, el destacado promotor del "arte sacra" romano quien se enroló en la misma Orden en España, por aquella época y cuyas ideas fueron tan decisivas para el desarrollo de Scipione Pulzone (Figs. 10 y 11 ). Es cierto que Valeriano aún no había contribuido entonces a plasmar el mencionado estilo de tlustración religiosa. Pero del contacto de Valeriano con el medio jesuita español al menos hubo una consecuencia fundamental para el futuro desarrollo americano: el viaje de Alesio al Perú y tal vez la migración posterior de otros pintores italionos a Lima (38).

El estilo que Bitti llevó a América estuvo claramente delimita-

último manierismo de la escuela limeña, Cultura Peruana. Nos. 167-170, Lima, 1962; F. Stastny: Pintores y Catedráticos. UNMSM. Lima, 1975; F. Stastny: La pintura en Eima de 1550 a 1640. Tesis, UNMSM. Lima, 1969.

(35) Véase Parte IV y nota 24.

(36) Bitti ingresó a la Orden de Jesús el 2 de Mayo de 1568. $\mathbf{R}$. Vargas Ugarte: Ensayo de un diccionario de artífices de la América Meridional. Burgos, 1968, 84. Sobre la actitud de la Compañía en relación al arte religioso véase: $\mathbf{R}$. Wittkower y I. Jaffé: Op. cit.

(37) Véase nota 44.

(38) La fecha de ingreso de G. Valeriano a la Compañía de Jesús, en España, ha sido publicada por diversos autores como 1572 y 1574 . En todo caso ambos artistas jesuitas coincidieron en España en 1574. Que se haya producido un encuentro entre ellos es una hipótesis. Pero es evidente que a raiz de la experiencia española de Valeriano, éste sirvió de enlace entre la Orden y los artistas italianos, que como M. Pérez de Alesio, fueron atraidos hacia el mundo americano. Este punto es tratado más ampliamente en el estudio sobre Pérez de Alesio que tiene en preparación el autor. Véase: F. Zeri: Op. cit., 70: R. Taylor: Hermetism and mystical architecture in the Society of Jesus. Appendix A, en: $R$. Wittkower y I. Jaffé: Op. cit., 92; Vargas Ugarte: Op. cit., 85:- M.S. Soria: La Pintura del siglo XVI en Sudamérica, Buenos Áres, 1956, 46: J. Mesa, T. Gisbert: Op. cit., 18 ss. 
do por las preocupaciones de la contra-maniera. Las figuras están siempre colocadas frontalmente o en pleno perfil; predomina un arreglo simétrico; la atención es concentrada en un contenido religioso fácilmente inteligible; el espacio es tratado con timidez. Aunque muestra preferencias por un "canon" alargado, no usa sino muy excepcionalmente un tímido movimiento serpentinato y los personajes religiosos están "honestamente" cubiertos con amplios drapeados de pliegues acartonados. Muchos de los rasgos de este estilo no se deben sólo a su formación provinciana en las Marcas, sino que obedecen a una intencional vuelta al pasado. En 1564, cuando Bitti, contaba con 16 años y se iniciaba en el arte de la pintura, se publicó en su ciudad natal (Camerino) un libro que él debe haber conocido y que resume las nuevas nociones sobre la corrección de la pintura religiosa. Se trata de Due dialoghi... degli errori de'Pittori por Giovanni Andrea Gilio da Fabriano (39). Dedicada al Cardenal Alejandro Farnese, esta obra tuvo una gran difusión en Italia en la época y contenía conceptos que para un joven pintor con intensa vocación religiosa como era Bitti, debieron ser fundamentales. Gilio recomienda muy insistentemente la necesidad de respetar la corrección tradicional de la iconoarafía religiosa, de evitar el desnudo y las figuras extravagantes en los temas sagrados; reclama que los personajes y las escenas sean "honestas" (en el sentido pudibundo de la palabra); y en general hace una invocación para que los artistas vuelvan al estilo antiguo, anterior a Miguel Angel y abandonen, por consiguiente, la maniera (40). Característico de esta actitud retrospectiva en Bitti como en todo el arte ifaliano de finales de siglo, es encontrar satisfacción en los rasgos arcaizantes de la pintura flamenca tradicional (41). El origen de esa lendencia en Bitti puede detectarse en el arte de Henri van de Broeck o en Denis Calvaert (42). Aunque pudo haber sido asimilado de muchas otras maneras y haberse

(39) E. Male: Op. cit., 2, n. 5; F. Zeri: Op. cit., 30-32.

(40) La opinión muy distinta de Miguel Angel sobre estos problemas ha llegado hasta nosotros en los Diálogos transcritos por Francisco de Holanda. El genial florentino pensaba, correctamente, que un arte religioso auténtico no puede descuidar la calidad. La pintura puramente devota, pensaba "...piacera assai alle donne, principalmente a quelle molte vecchie, e a quelle motto giovani, e cosí pure ai frati, alle monache, e a quelche gentiluomo privo del senso musicale della vera armonia", Citado por F. Zeri: Op. cit., 32 y No. 1. nota 12 .

(41) F. Zeri: Op. cit., $20-40,59,80,82-90$, etc. Véase también

(42) La relación con $\mathrm{H}$. van den Broeck es notorla, por ejemplo, en la Crucifixión (S. Juan, Juli) de Bitti, donde la figura del San Juan es casi igual al de la Deposición de Cristo (Ss. Trinita, Viterbo) de Van den Broeck. Dipinti Fiammenghi di Collezioni Romana. Roma, 1966, fig. 16, y J. Mesa, T. Gisbert: Op. cit., fig. 49. 


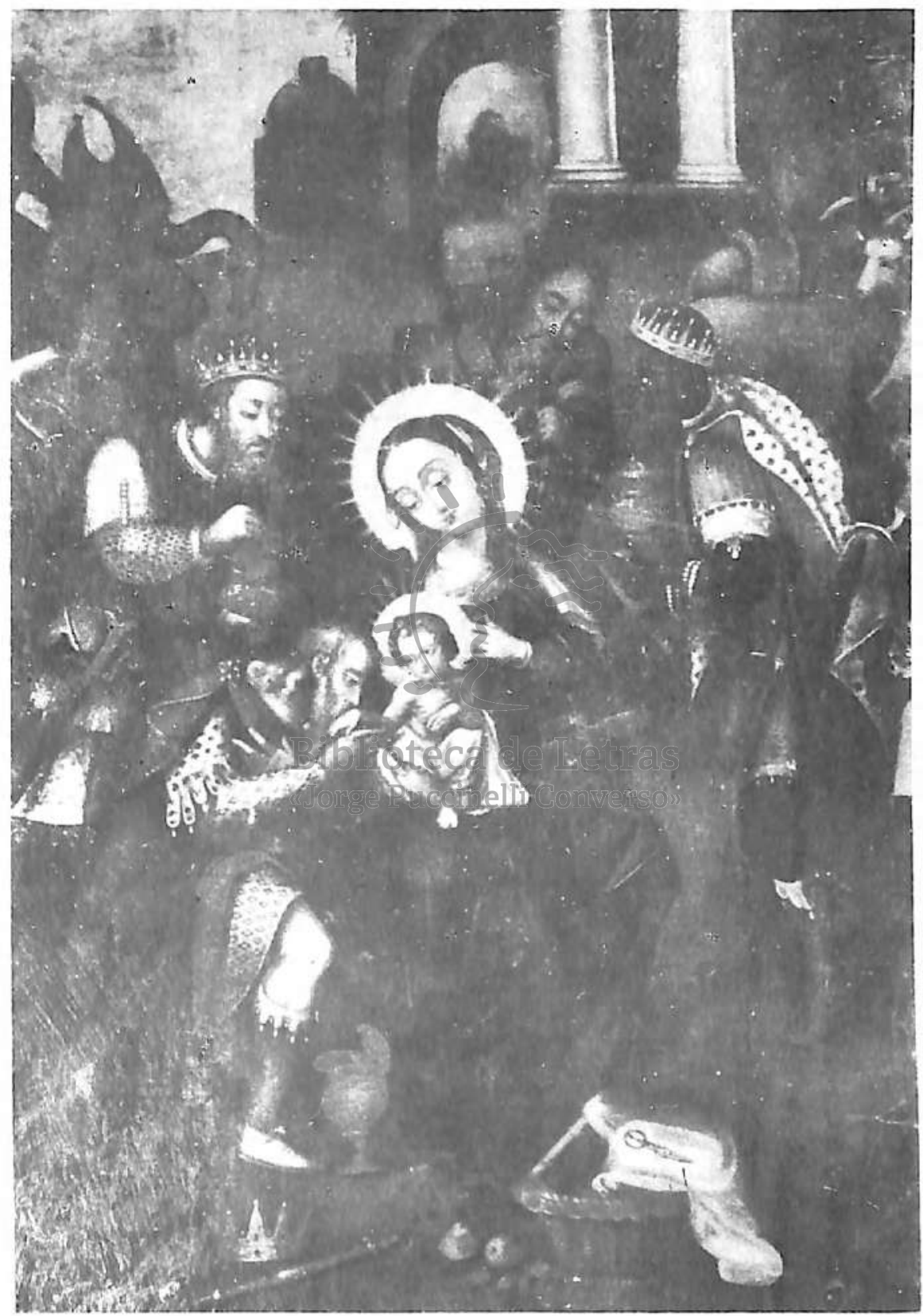

in Gregorio Gamarra: Adoración de los Reyes Museo Nacional, La Paz. 


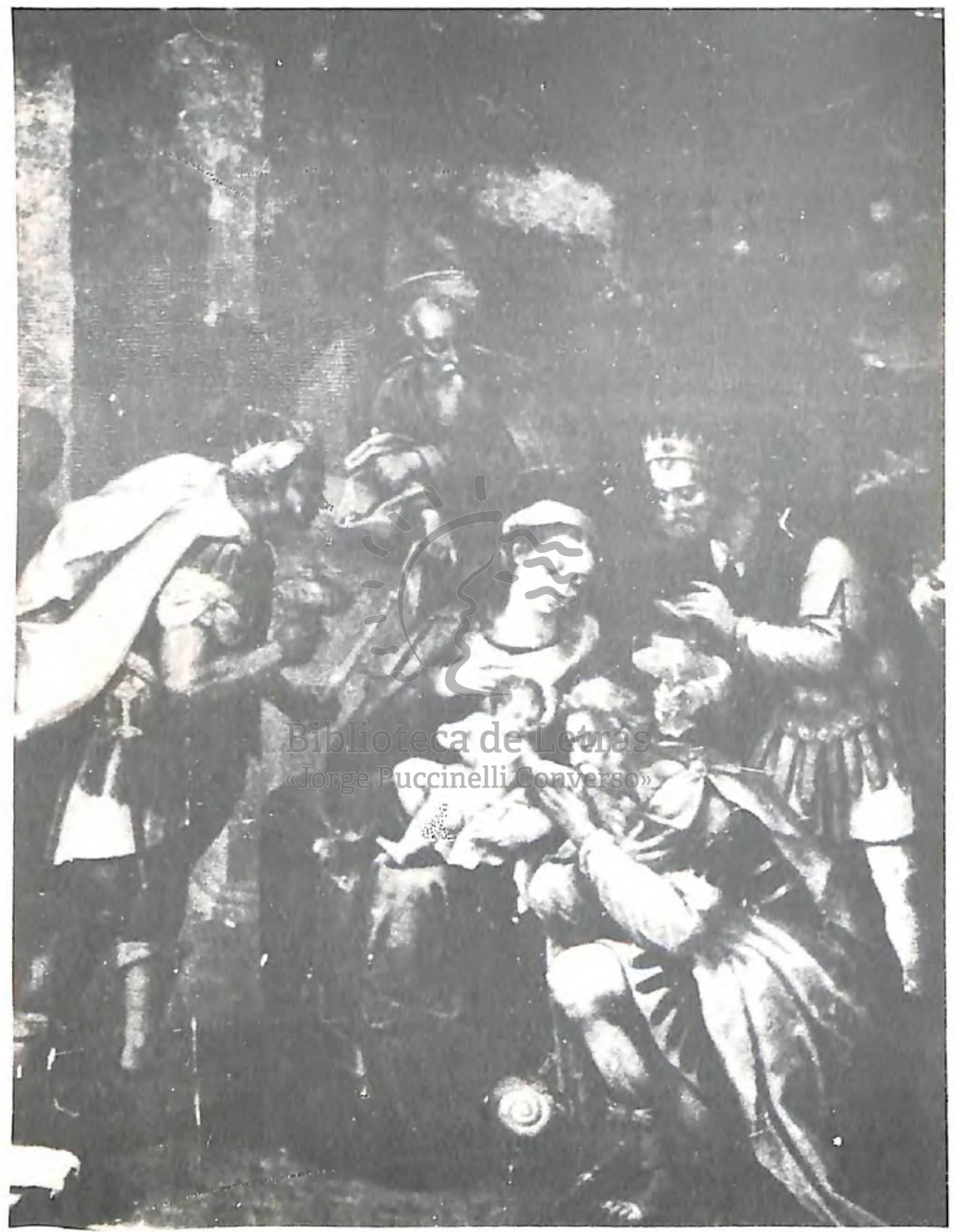

Fot. 2. Simón Pereyns: Adoración de los Reyes 1586. Iglesia de Huejotzingo. 


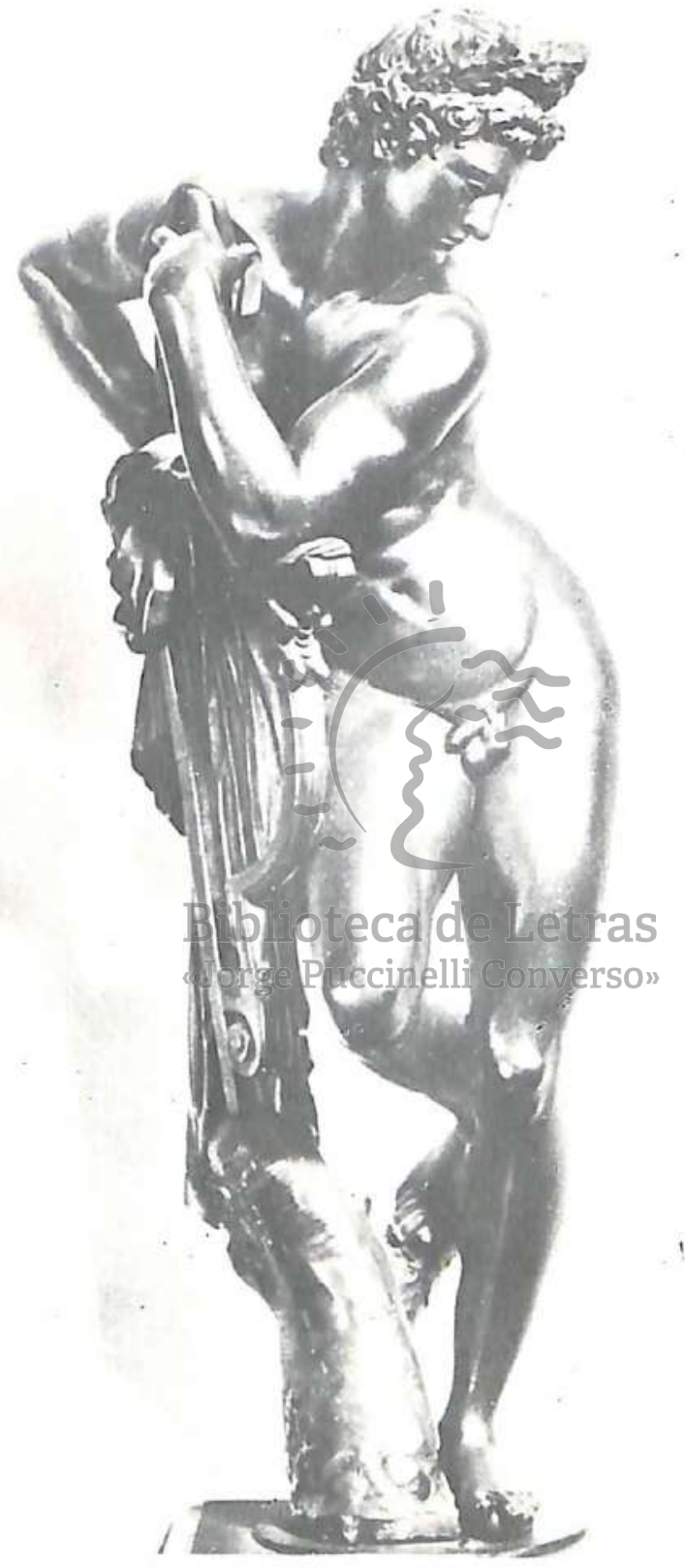
Fot. 3. Giambologna: Apoyo Studiolo de Francisco i, Palacio Vec-
chio, Florencia. 


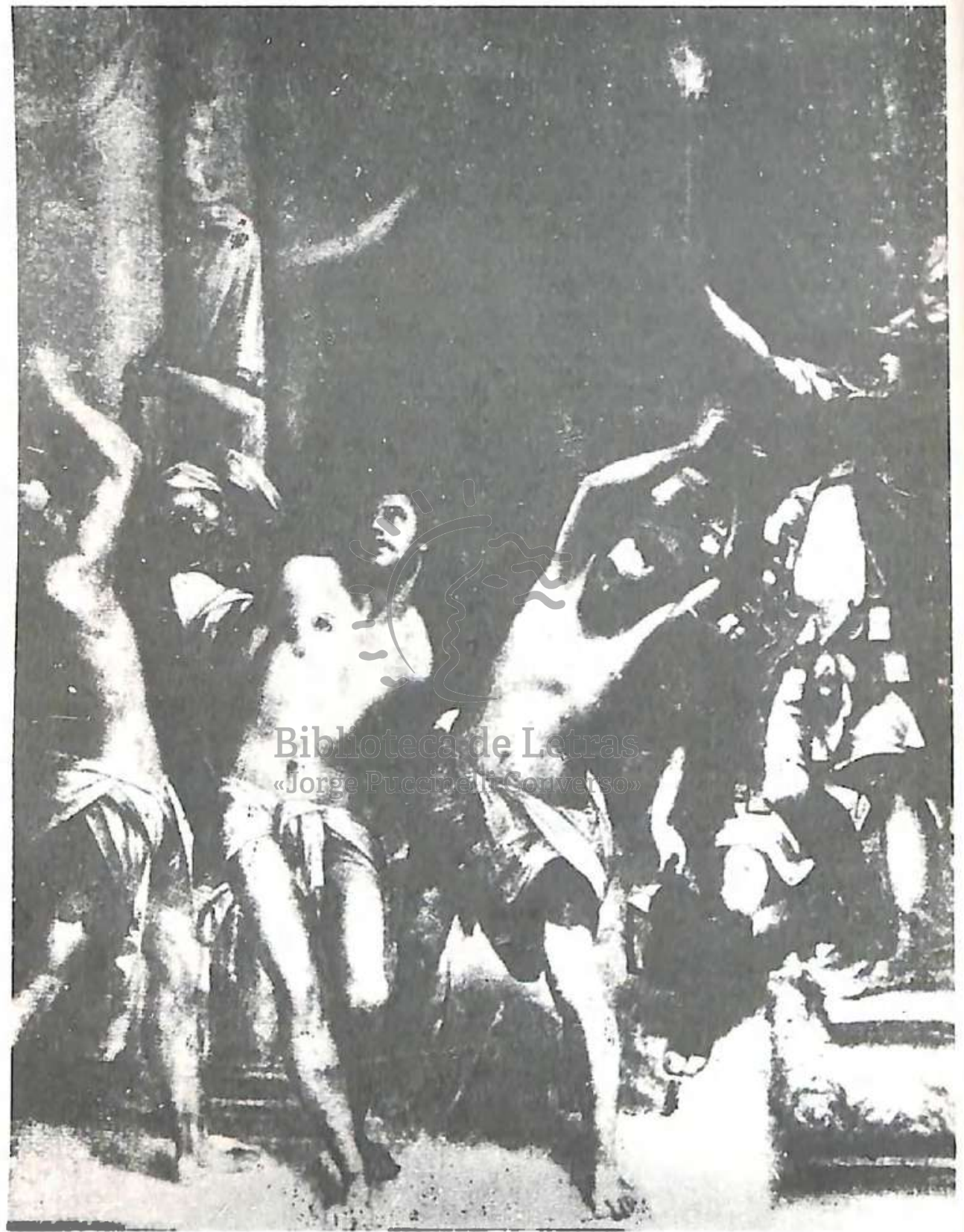

Fot. 4. Angelino Medoro: Flagelación de Cristo. Ex-Colección Tristán Sevilla. 


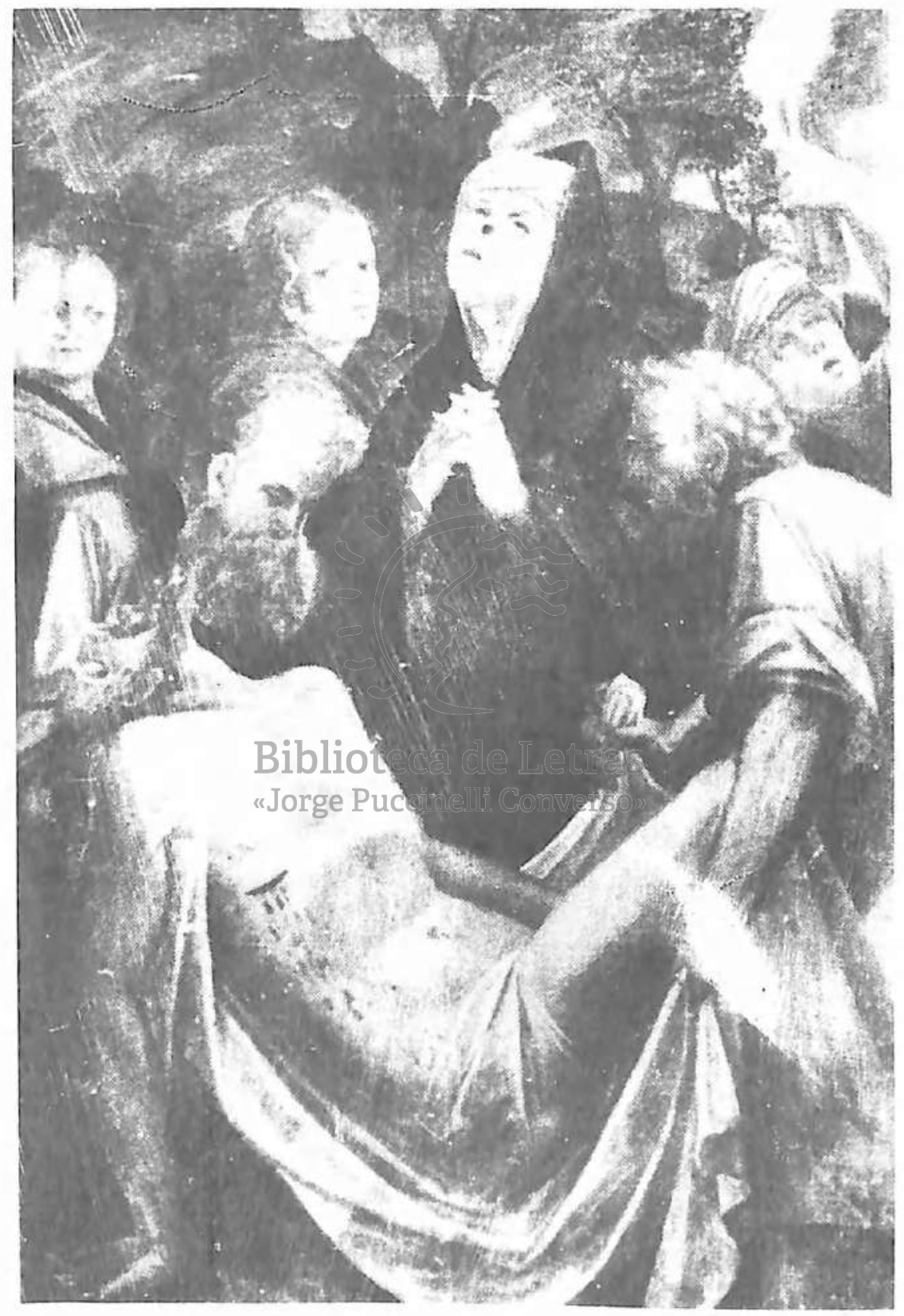

Fot. 5. Angelino Medoro: Entierro de Cristo Catedral, Tunja 


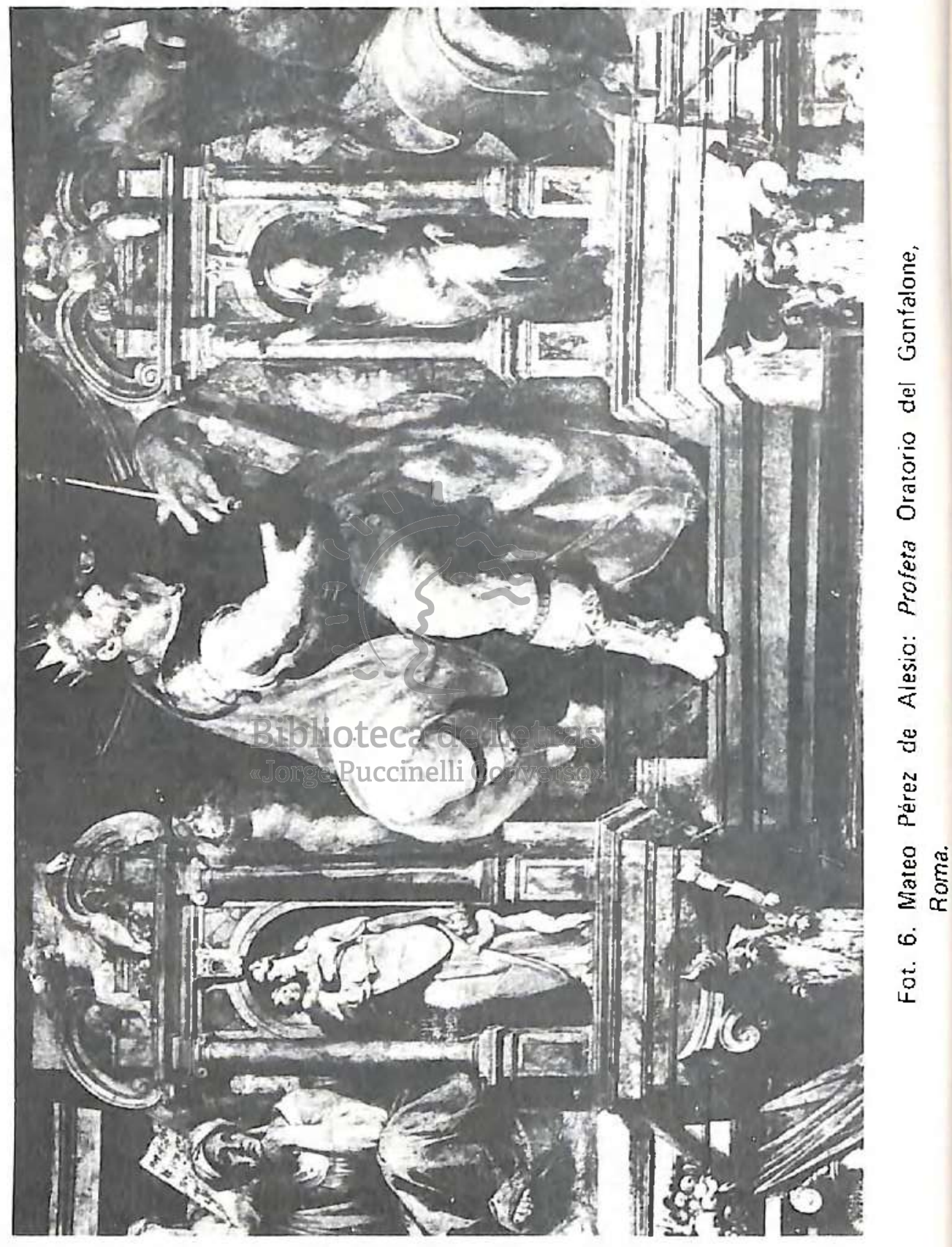




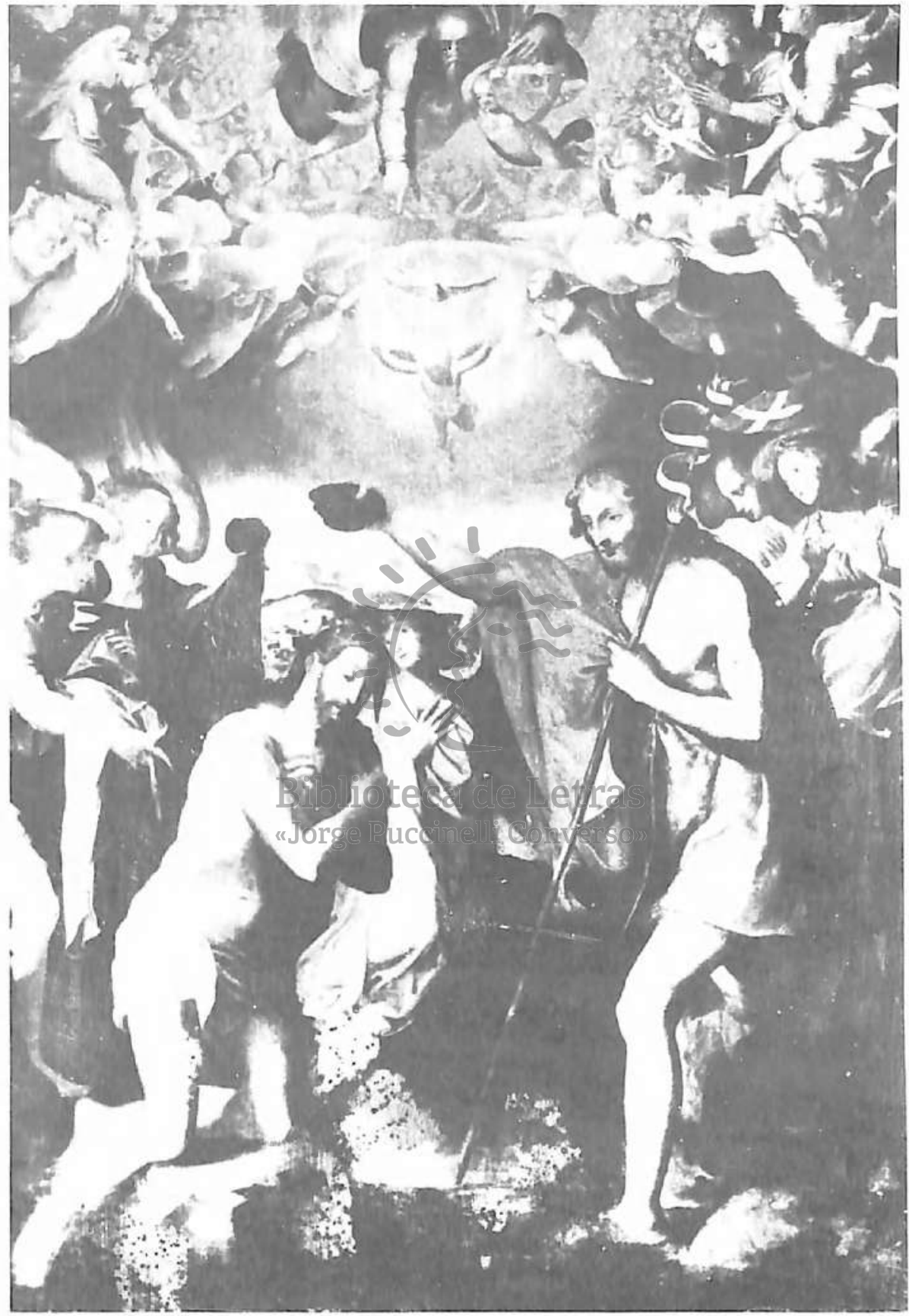

iot. 7. Mateo Pérez de Alesio: Bautizo de Cristo. Catedial, Valleta, Malta. 


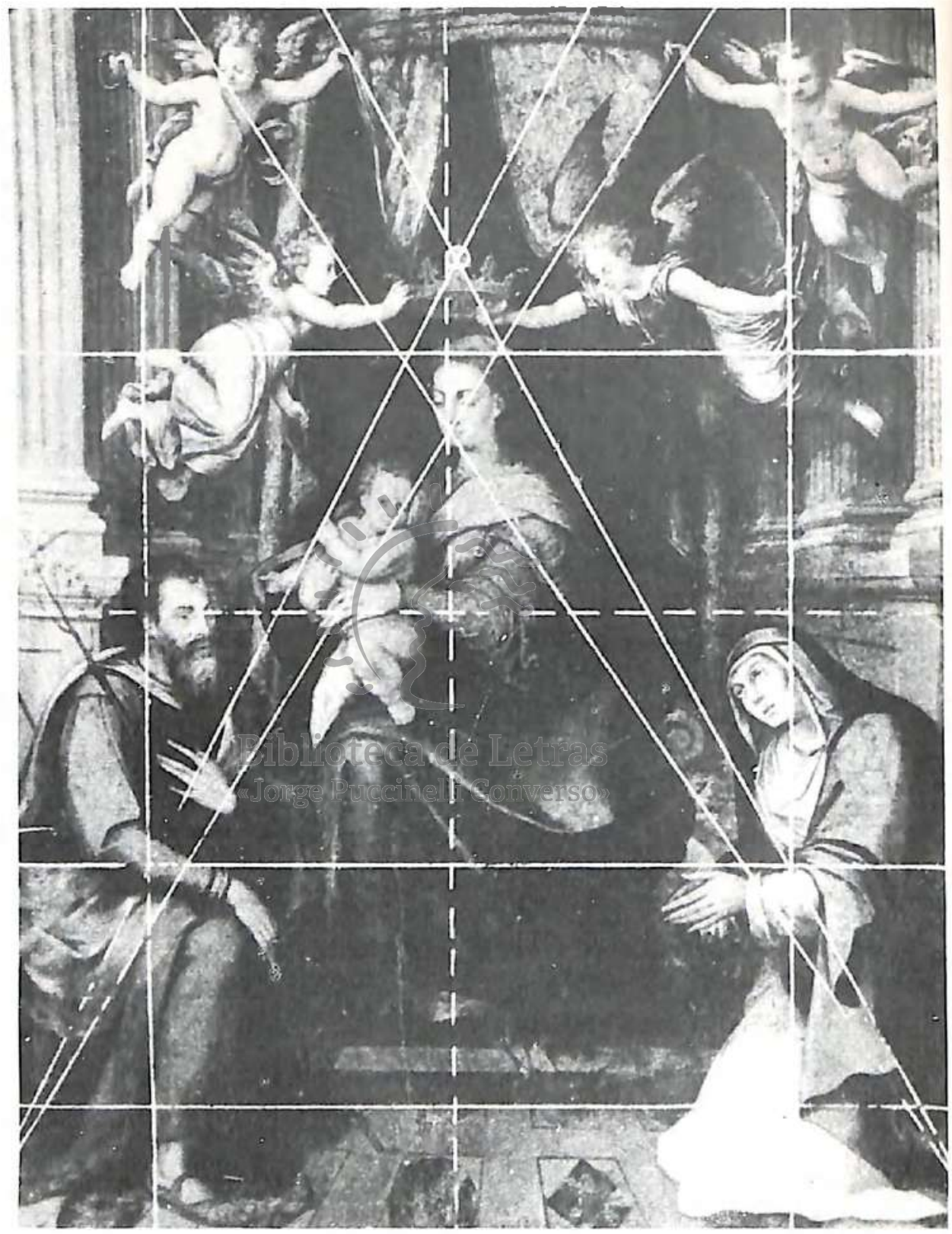

Fot. 8. Simón Perreyns: Virgen del Perdón. Antes de su destrucción, Catedral, México. 


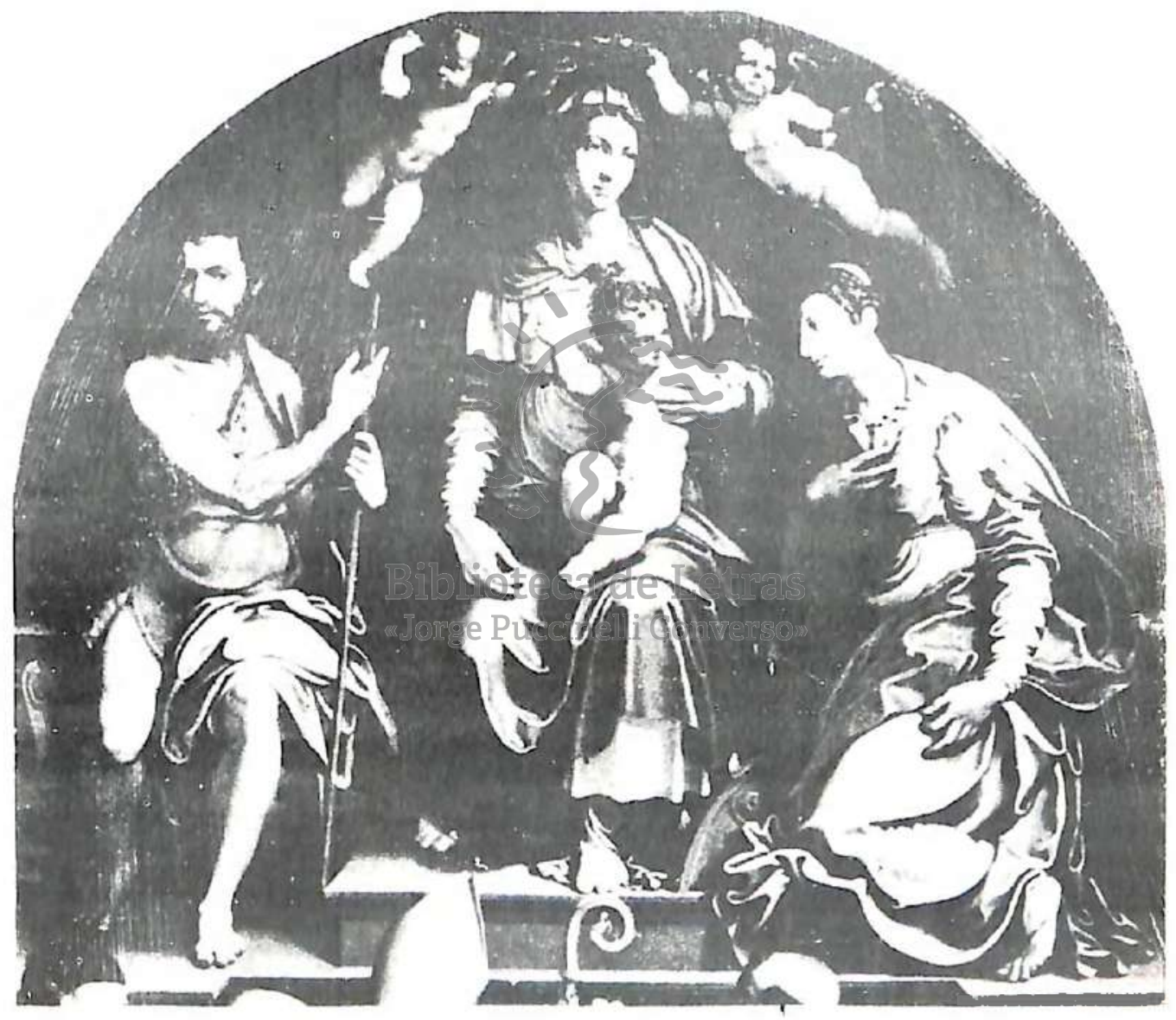

Fot. 9. Girolamo Siciolante: Madonna con seis santos (Pormenor). 1548. S. Martino Maggiore, Bologna. 


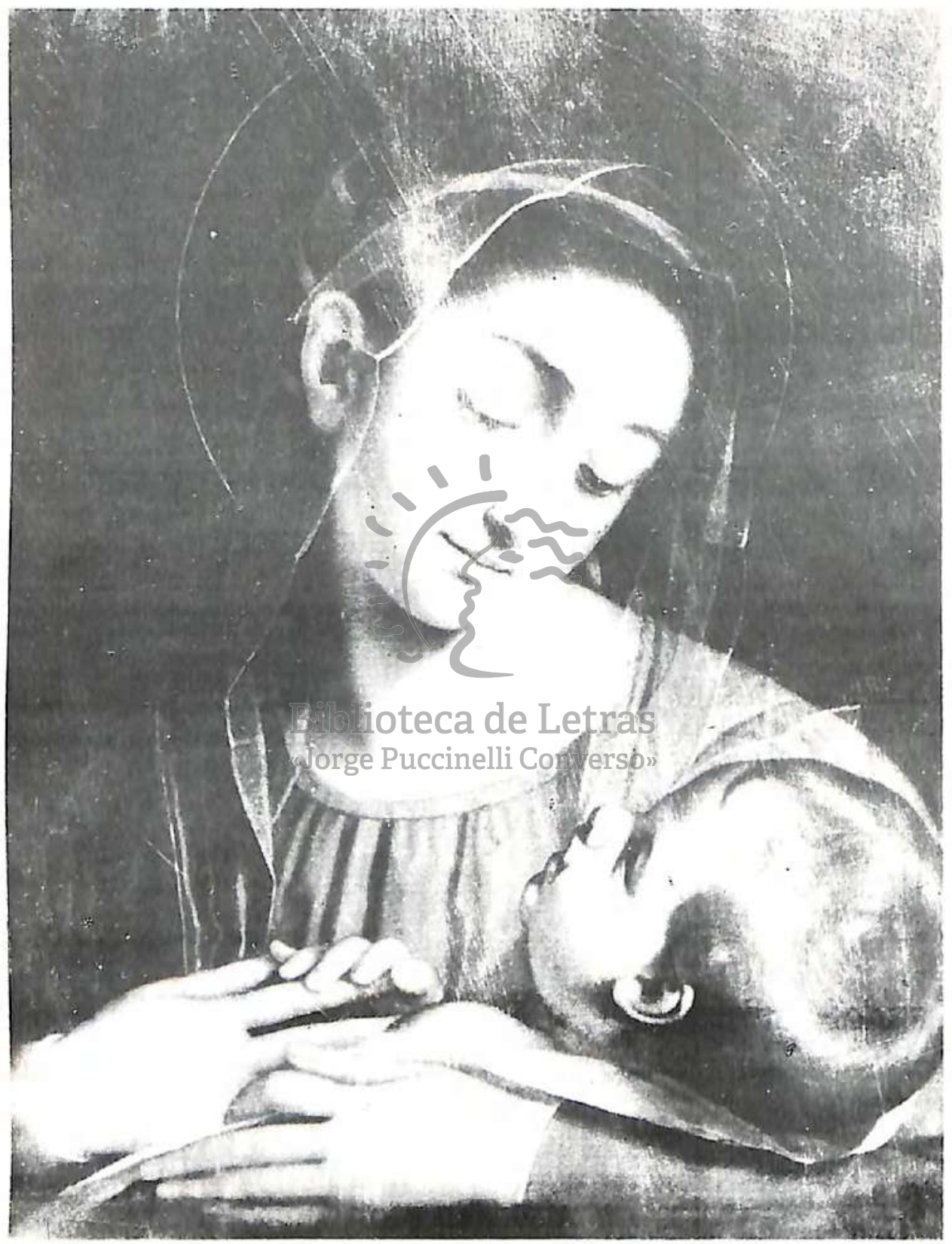

Fot. 10. Scipione Pulzone: Virgen de la Divina Providencia Convento de San Carlo ai Catinari, Ronia. 


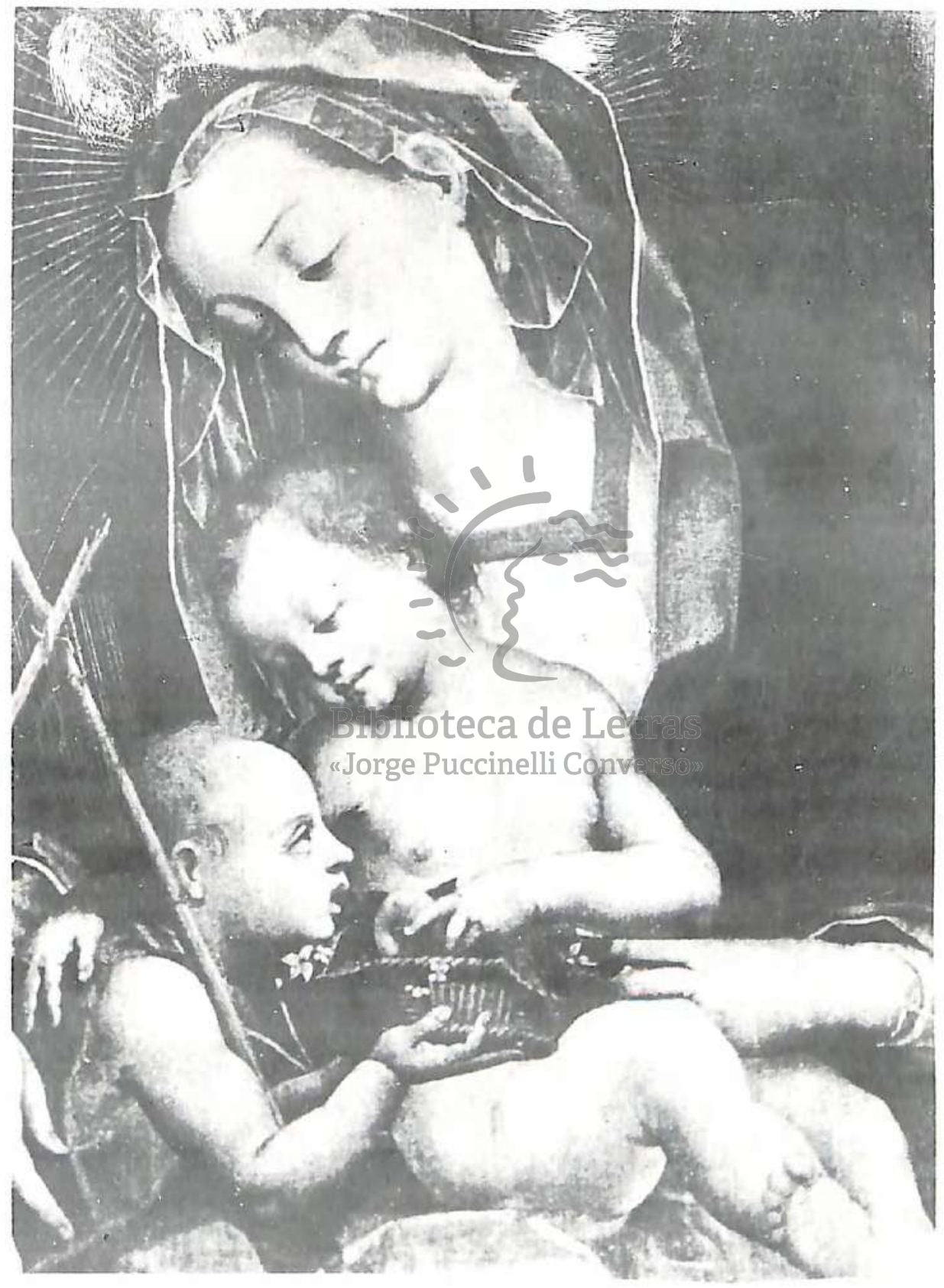

Fot. 11. Bernardo Bitti: Sagrada Familia con San Juanito. Museo de la Catedial, Sucre. 


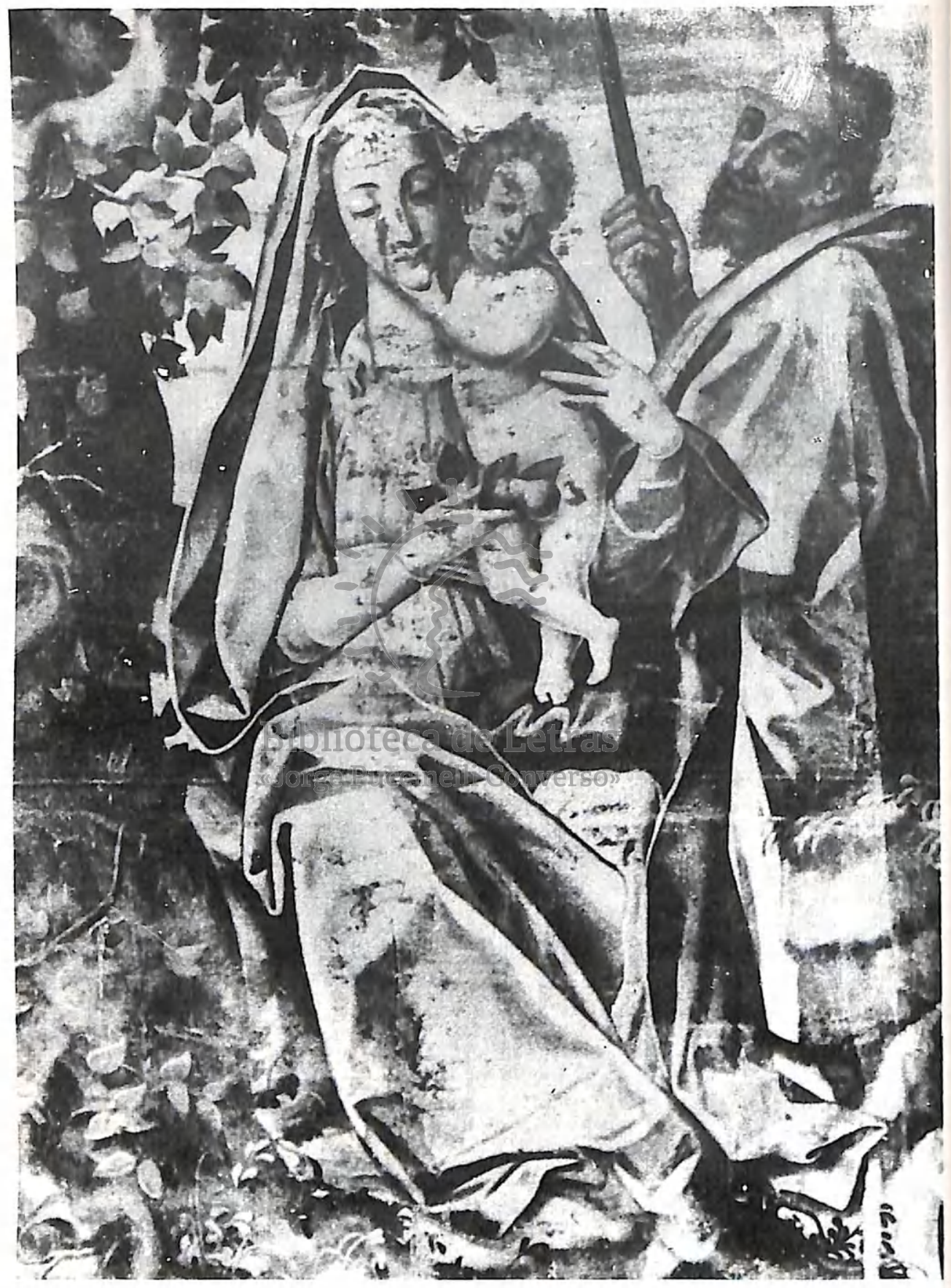

Fot. 12. Bernardo Bitti: Sagrada Familia de la Pera. La Asunción, Juli. 


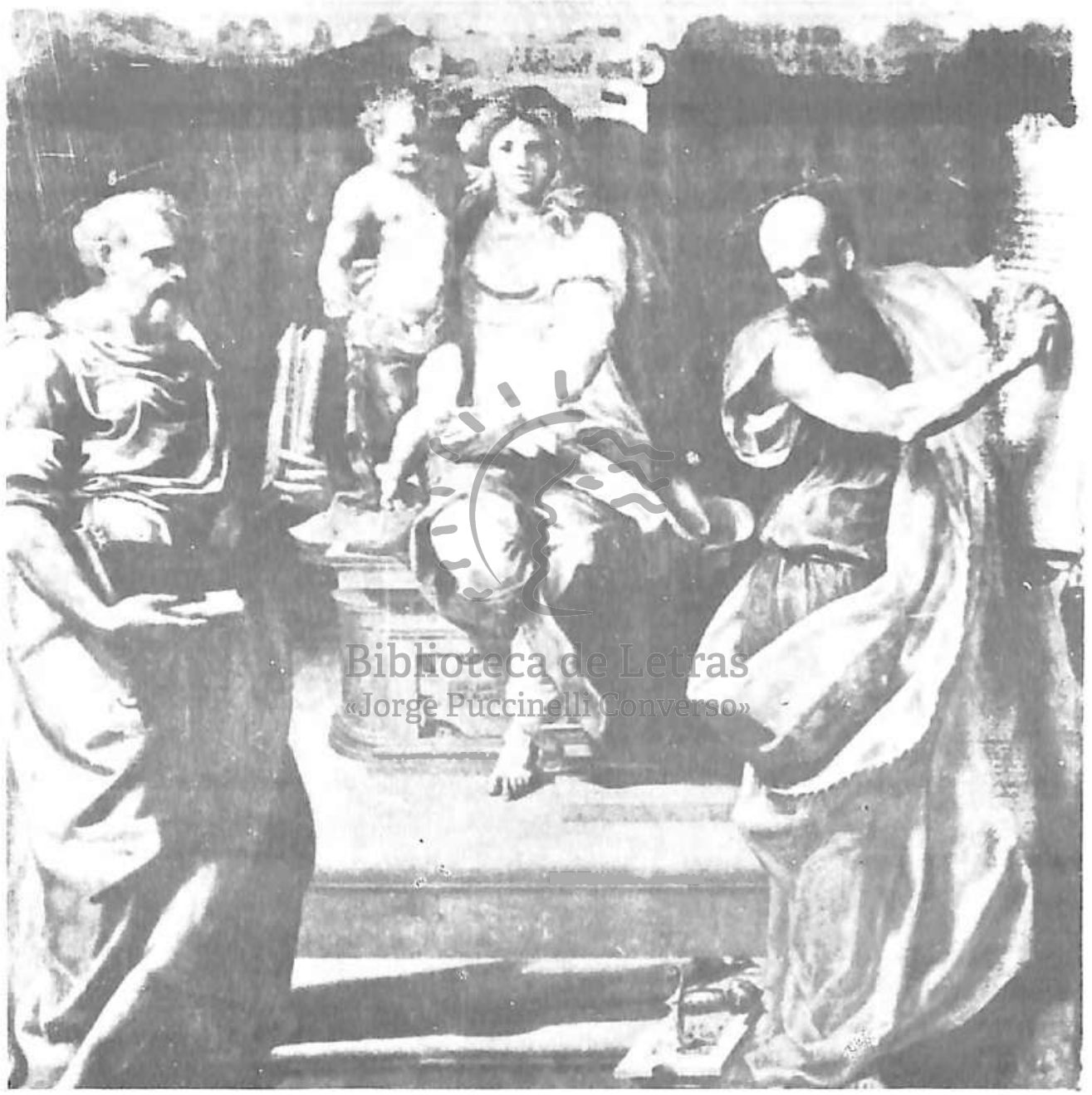

Fot. 13. Daniel de Volterra: Virgen con dos Santos Seminario, Volterra. 


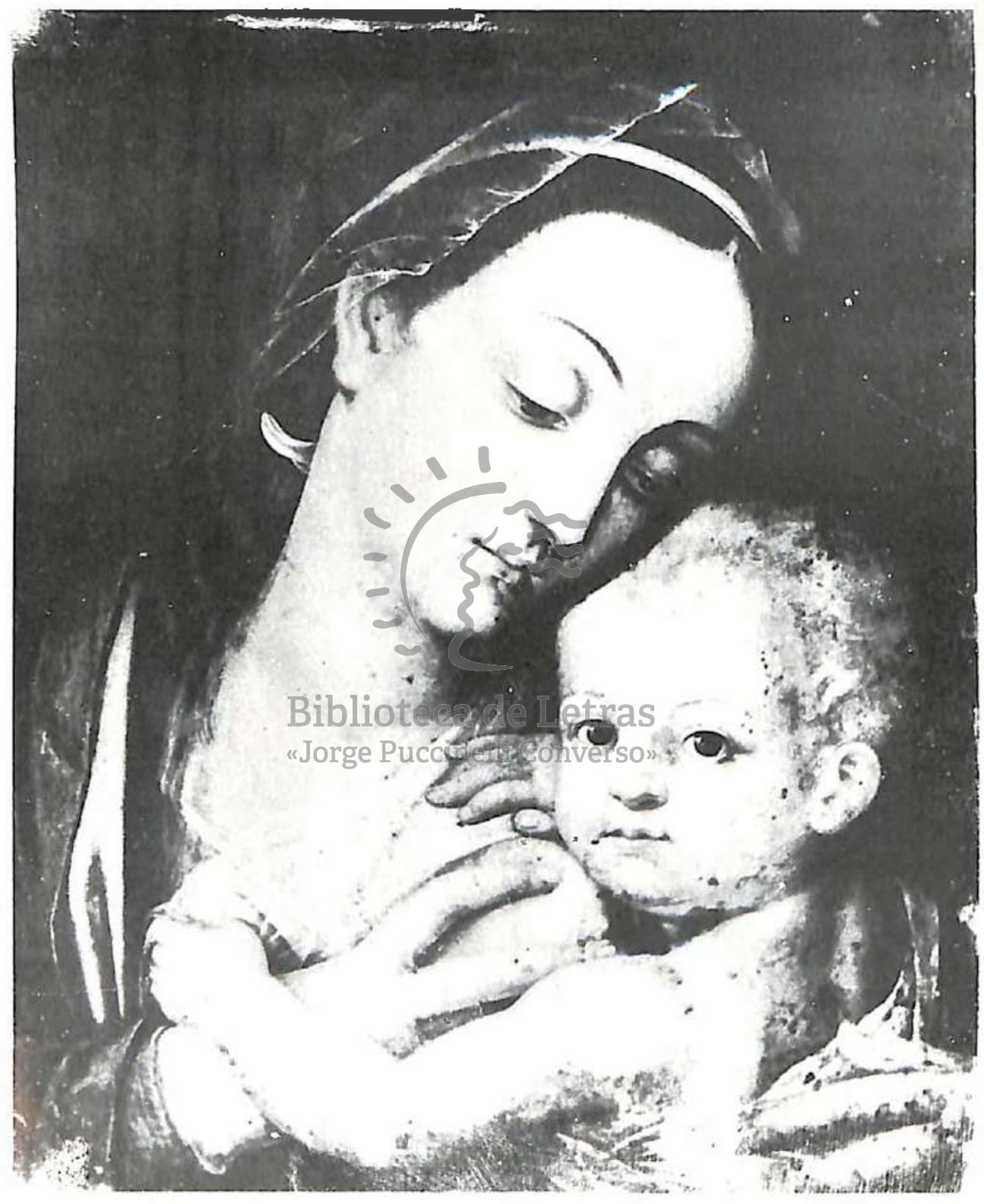

For 14. Mateo Pèrez de Alesio: Viryen di la lec's. Col. Parlicula, Lima. 


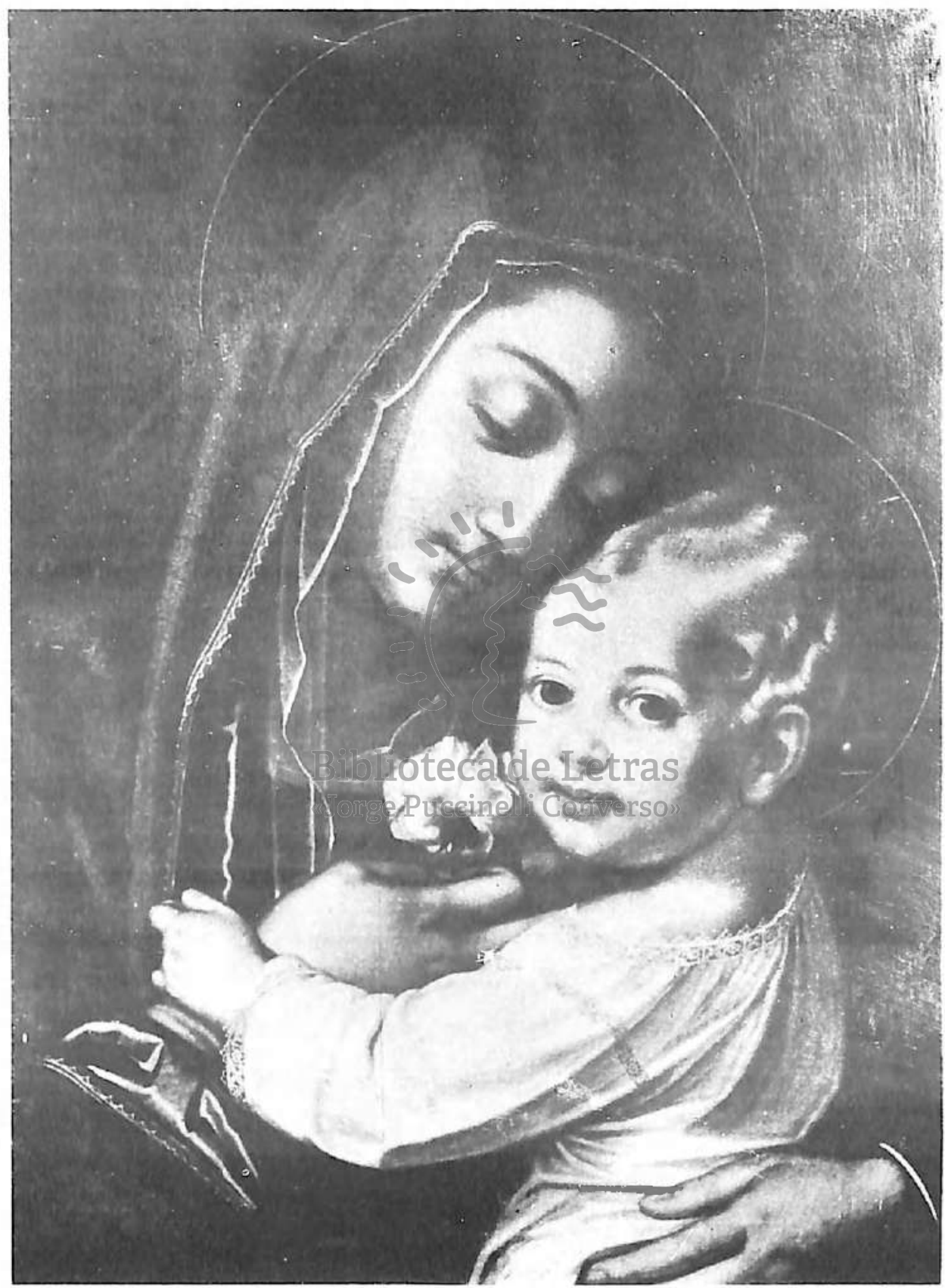

Fot. 15. Scipione Pulzone: virgen de la rosa. Galería Borghese, Roma. 


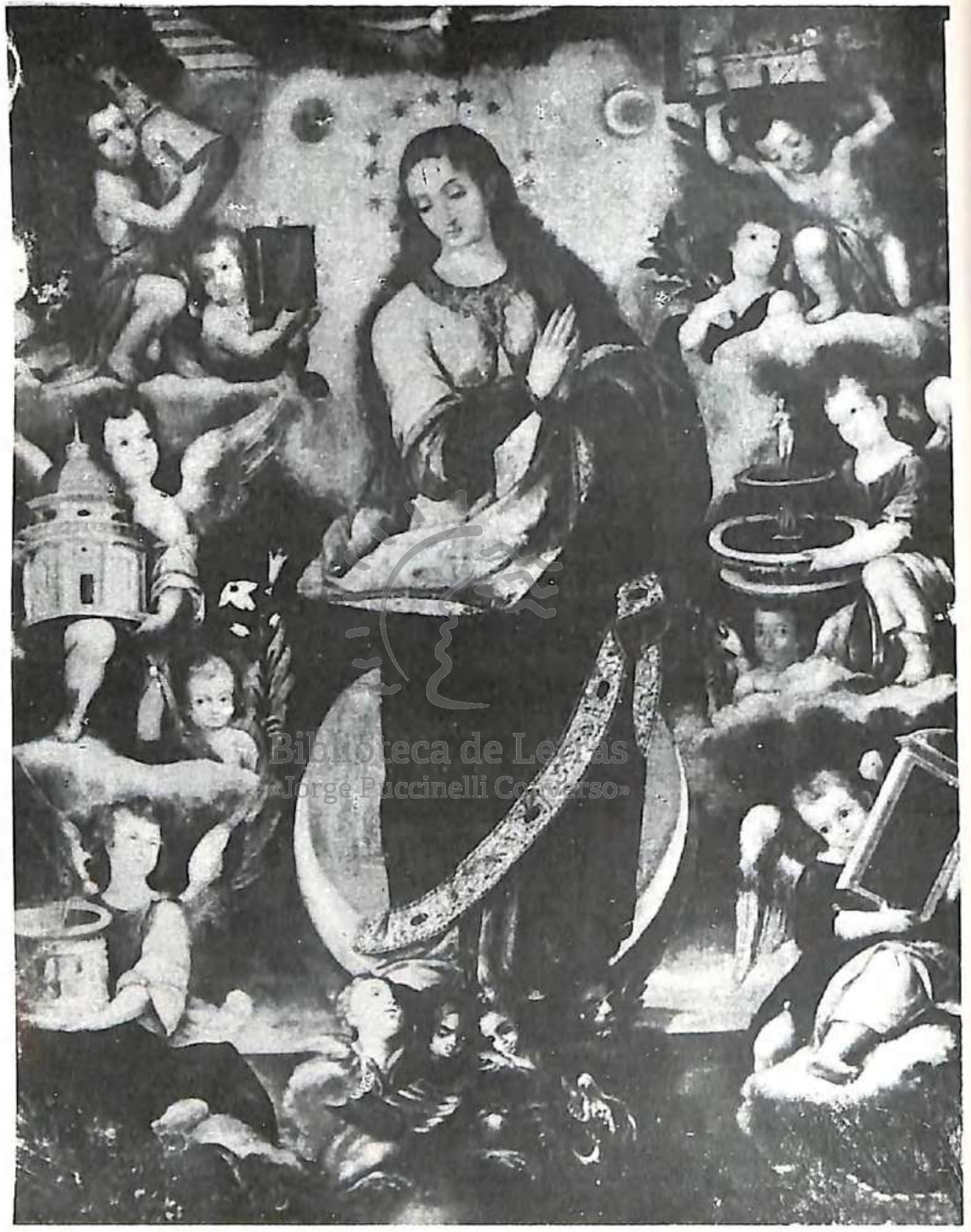

Fo1 i6. Angelino Medoro: Inmaculada Concepción lịlesia de San Agustin, Lima. 


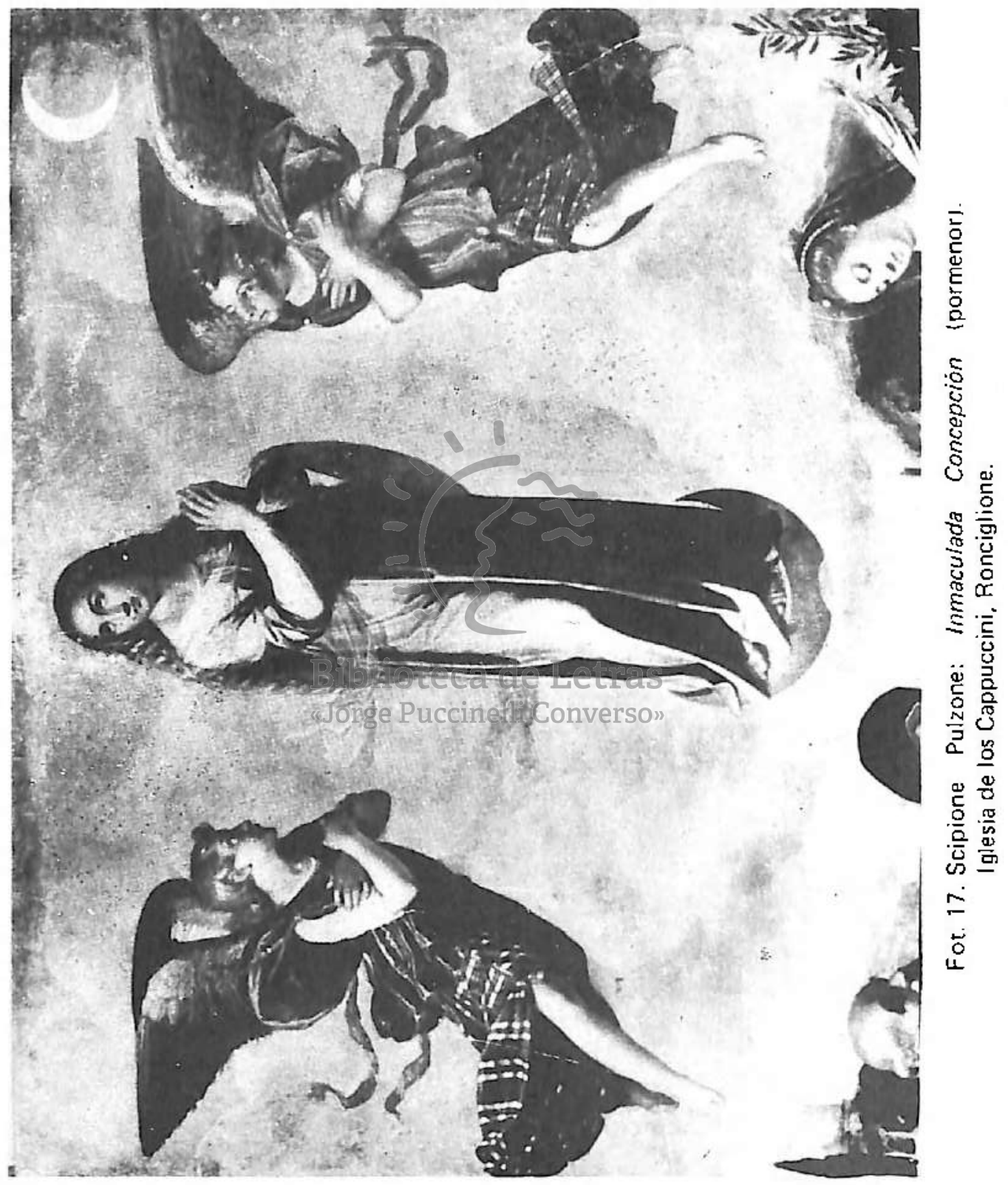




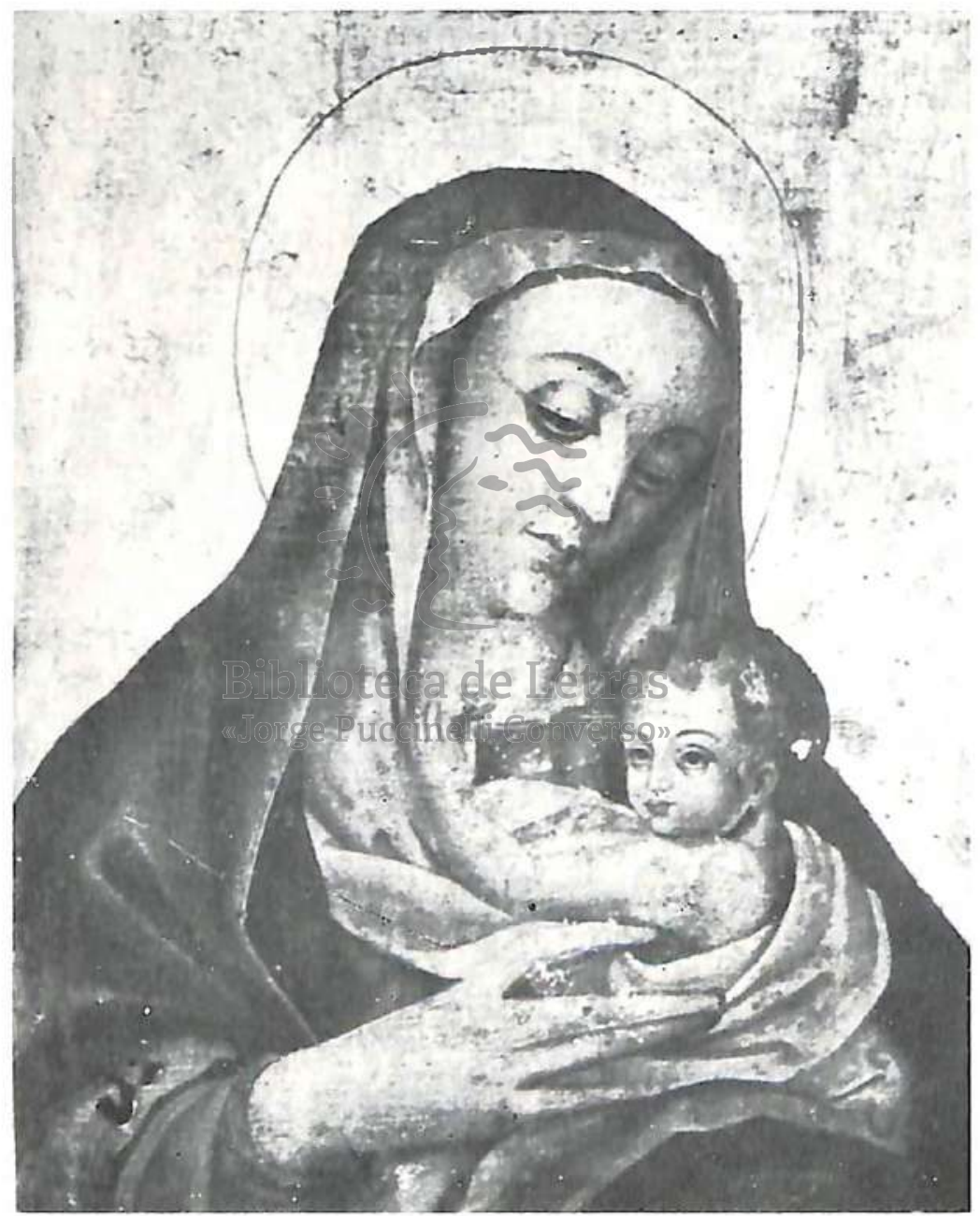

Fot. 18. Pedro Bedón: Virgen de la Rosa Colección Osma, Lima. 


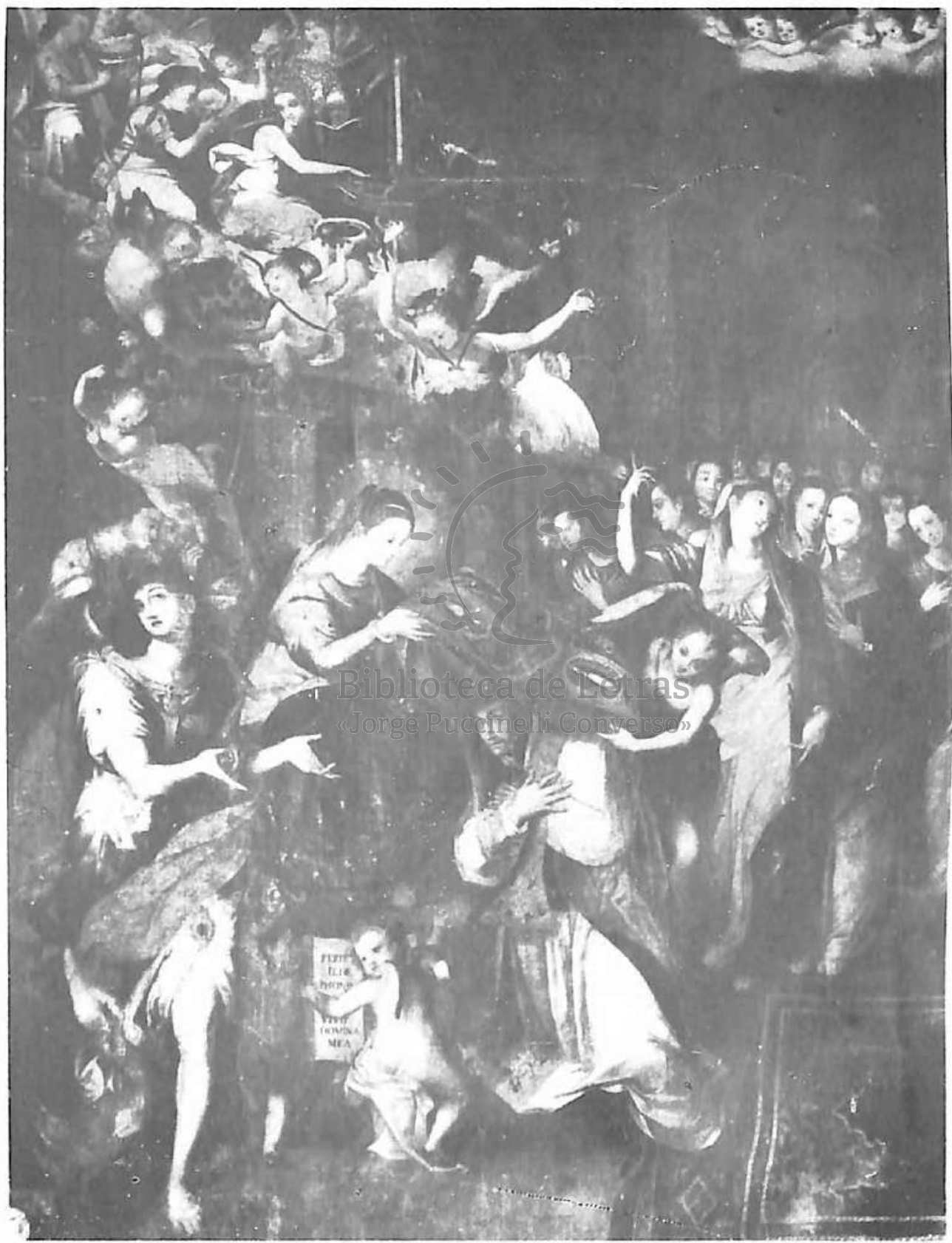

Fot. 19. Leonardo Jaramillo: Imposición de la Casulla a San l/defonso Convento de los Descalzos, Lima. 


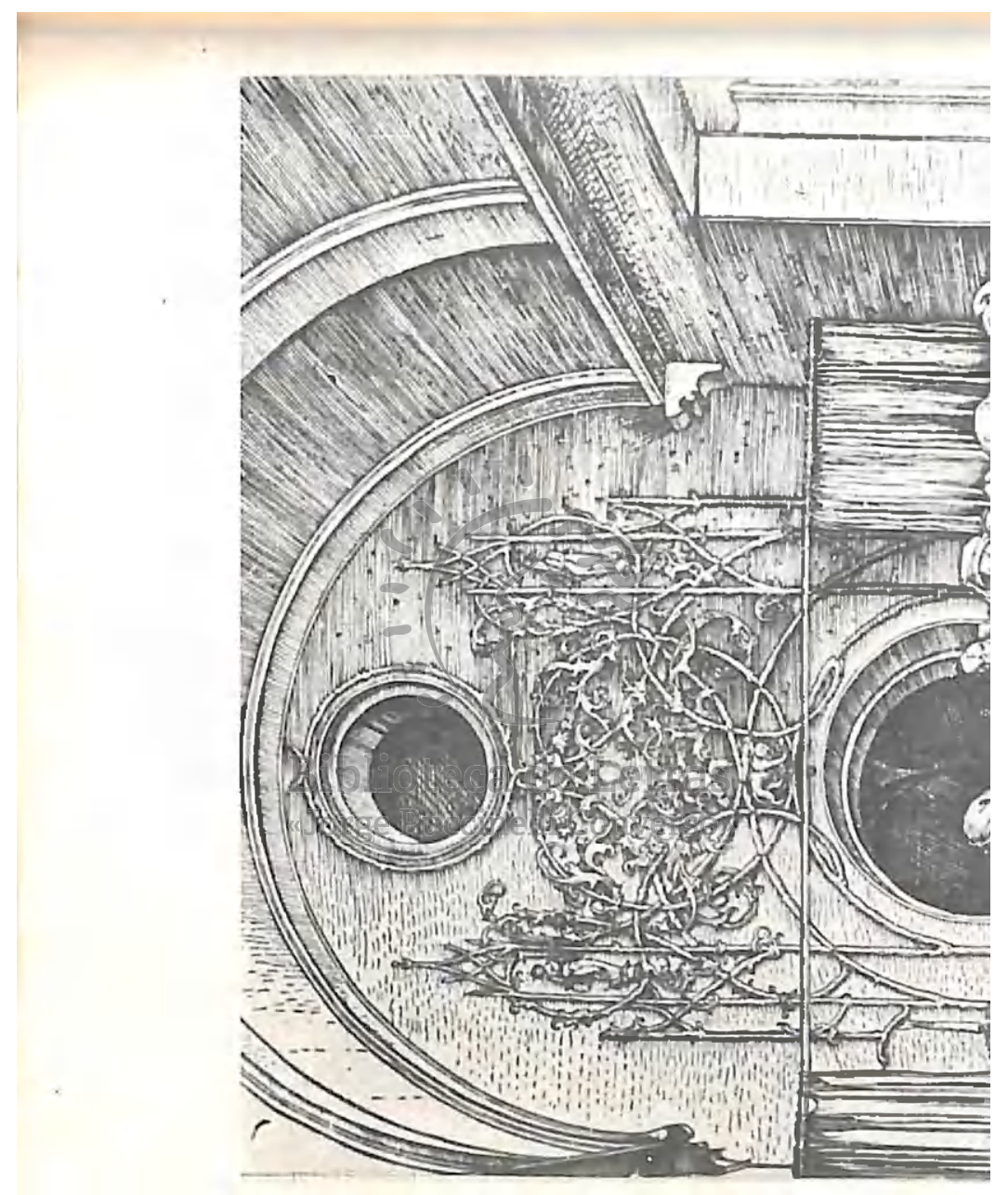




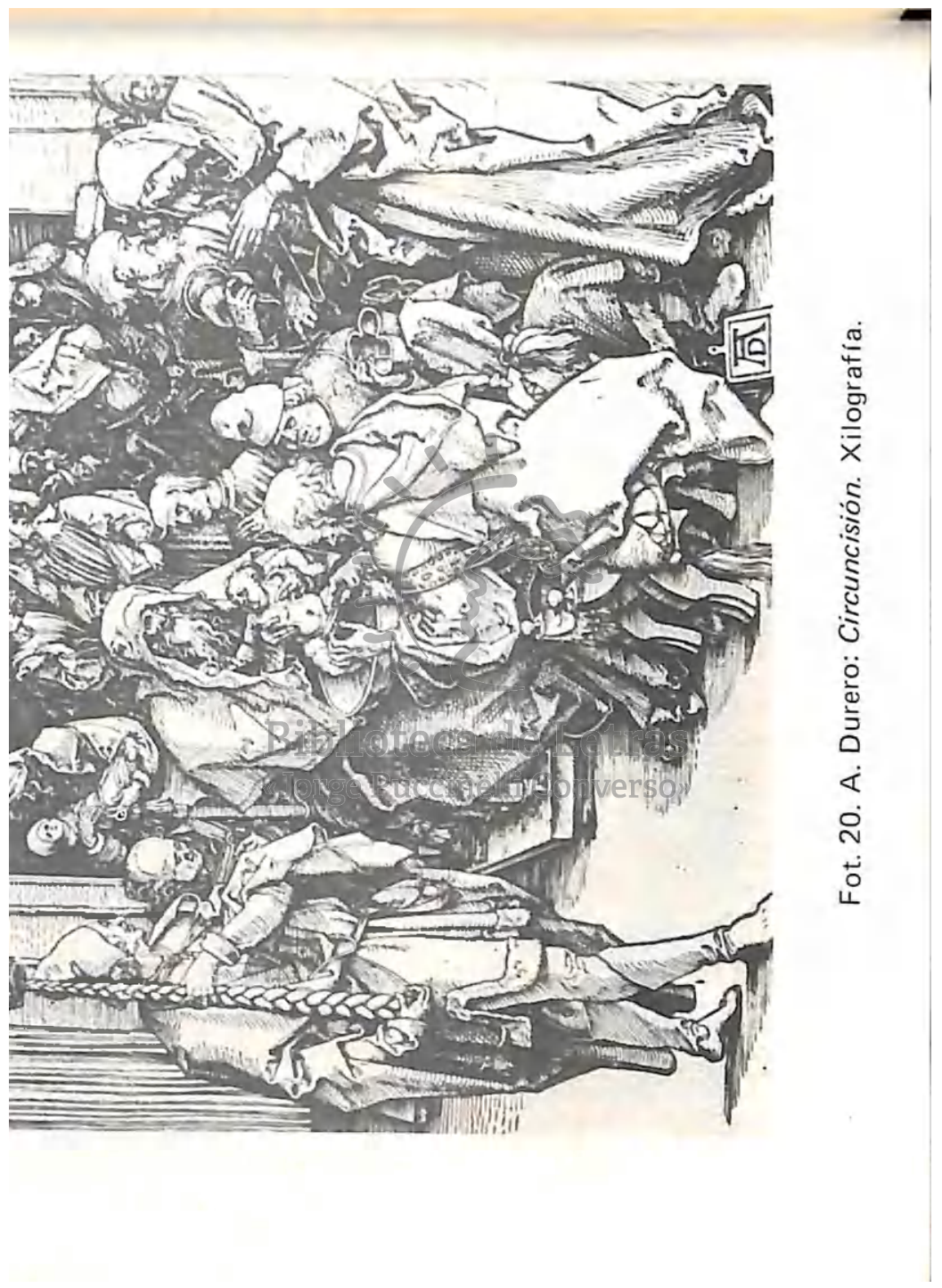


reactivado posteriormente en Sevilla a la vista de pinturas de Pedro de Campaña y Fernando Storm.

Entonces, la etapa inicial de Bitti en América estâ caracterizada por el marco contra-manierista de sus composiciones que recurren ocasionalmente a modelos extraídos de artistas de la primera fase reguladora como Daniel de Volterra (43) (Figs. 12 y 13) o Marcello Venusti. Y de una tendencia flamenca que lo indujo a una minuciosidad no muy alejada precisamente del miniaturismo de Venusti o de Clovio. Esta última inclinación explica la similitud de sensibilidad que se percibe en Bitti y un artista como Luis Lagarto, de Puebla; aunque el jesuita la tradujo a escala monumental para adecuarla a la decoración eclesiástica.

El estilo de Bitti sufrió, sin embargo, una escisión muy notoria a partir de 1592-93, cuando de regreso en Lima después de una larga ausencia, conoció la última novedad del arte italiano religioso: la anti-maniera. El portador de esas innovaciones fue Pérez de Alesio, quien por esos años repitió en la Ciudad de los Reyes algunas composiciones de éxito de Pulzone (44). Todas las obras de Bitti posteriores a esa fecha, y muy especialmente las de Sucre (Figs. 10, 11, 12), traducen ese nuevo sentimiento (45). Las ca-

(43) Compárese, por ejemplo, el niño Jesús de B. Bitti: La Virgen de la pera (S. Pedro, Juli) con D. de Volterra: Virgen con San Pedro y San Pablo (Seminario, Volterra). M.S. Soria: Op. cit., fig. 21 ; S. J. Freedberg: Op. cit., fig. 206.

(44) La de mayor éxito fue la Virgen de Belén o de la Leche de la cual se conservan en el Perú y Bolivia numerosas versiones producidas por Alesio y su táller. Publicamos en 1969 la mejor de aquellas pinturas (Col. Velarde, firmada en el grabado del reverso) y la asociamos hipotéticamente a lagVirgen dee Belén quessanto Toribio de Mo-. grovejo encargara en Abril de 1604. Apoyándose en esa fecha circunstancial Mesa-Gisbert (Bitti, un pintor manierista. La Paz, 1974, 74, 113) procuran poner en duda la influencia ejercida por Alesio sobre Bitti en 1592 . Sin embargo nuestro texto es muy claro: la de 1604 no fue sino una de las abundantes versiones idénticas entre sí confeccionadas en el taller de Alesio desde su llegada a Lima en 1588-90. Véase F. Stastny, Op. cit. y las notas 45,46 de este artículo.

(45) La semejanza entre la Virgen de la Catedral de Sucre de Bitti (fig. 10) y la Madonna della Divina Providenza de Pulzone (fig. 9) es tan grande que es imposible explicar la similitud por otro expediente que el del conocimiento que Bitti tuvo de los modelos de Pulzone por intermedio de Alesio con quien se encontró en 1592-93 en Lima. Muy lejos, entonces, de "afirmar su fe en el manierismo", como creen J. de Mesa y T. Gisbert (Bitti, un pintor manierista. La Paz, 1974, 74), Bitti adoptó sin reservas la nueva modalidad de la anti-maniera después de su contacto con Alesio. Fue esa variante estilística la que se desarrollaba entonces en Roma y sus raices estaban en la propia iglesia del Gesú, la matriz de la Orden. Es normal que Bitti, obediente hermano de la Compañia, la aceptara tan plenamente. Véase también F. Stastny, $\mathbf{O p .}$ cit., 26-35. En cambio, el manierismo, todo lo contrario de "vigorizarse y ampliarse" en esa época como lo afirman Mesa-Gisbert (Loc. cit.), se 
bezas de sus figuras femeninas son las que revelan más patentemente la transformación producida en el artista jesuita. En vez de la posición frontal o en perfil que habitualmente otorgaba a sus representaciones de la Virgen, desde ahora pintará a María con el rostro cabizbajo, inclinado hacia la derecha y con una expresión melancólica en todo semejante al modelo de Alesio. Además de la serie de Sucre, la Virgen con el Niño de la Compañía de Arequipa ilustra con toda claridad esa nueva tendencia en Bitti.

El papel que jugó Mateo Pérez de Alesio en Sud-América, entonces, está claramente definido, como consecuencia de una situación social a la cual ya nos hemos referido anteriormente y de la cual Alesio es fiel reflejo. Dspués de sus inicios en Roma bajo la influencia de Taddeo Zuccari y haciendo gala de un miguelangelismo violentó en sus obras del Gonfalone (1575) (Fig. 8), Alesio debió transforma totalmente su estilo a una contra-maniera atenuada para adaptarse a las exigencias religiosas de la Orden de los Caballeros de Malta (Fig. 7). En 1588 cuando llegó a Lima trajo consigo el bagaje de esas experiencias y sobre todo la nueva modalidad de Valeriano y Pulzone (Figs. 14, 10, 15), cuya aplicación fue tan adecuada a las necesidades eclesiásticas del Virreinato. La Virgen de la leche creada en Lima por Alesio en base a dos modelos de Pulzone, tuvo un éxito inmediato y perdurable en la sociedad virreinal peruana. Santa Rosa de Lima, quien fue su contemporánea, rezó y tuvo visiones frente a una de las versiones de esa composición. Un sinnúmero de réplicas fueron producidas por el taller del pintor y a partir de entonces el tema de la Virgen de Belén, como sé lá llamaba en la época, se convirtió en uno de los motivos predilectos de la pinturg limeña y cuzqueña (46).

encontraba en plena retirada y transformación. ¿Será necesario recordar que en la década de 1590 ya estaban trabajando en Roma Caravaggio, para el Cardenal del Monte, y Annibale Carracci, para el Cardenal Farnese?

(46) Alesio transformó la Virgen de la Rosa de Pulzone en una Virgen de la leche, usando como modelo para la cabeza de María otra composición de Pulzone: la Sagrada Familia de la Galería Borghese. El éxito que alcanzó la composición motivó que Alesio produjera con sus ayudantes gran número de réplicas, casi todas sobre cobre, con las mismas medidas y con exactamente la misma composición. El haberse hallado en una de éstas una inscripción en el reverso que todavia no ha sido publicada pero que aparentemente puede interpretarse como la firma de Morón, ha inducido a que $\mathrm{J}$. de Mesa cuestionara la paternidad del cuadro firmado de Lima. El estudioso boliviano pretende asi, desconocer que Morón trabajó durante 23 años como mero asistente o factótum de Alesio, cuyo estilo imitó fielmente. $Y$ desconoce efectivamente la relación de Alesio con Pulzone en Roma la cual está probada con documentos de archivo. Querer deducir sobre la base de esa inscripción, como lo hace Mesa, diferencias de estilo entre Morón y Alesio es una "argumentación logistica" (sic) muy pobre, la cual ignora la transformación profunda producida en la obra de Alesio a partir de su viaje a Malta. 
Como en el caso de los artistas italianos del mismo periodo, Alesio tampoco fue un practicante exclusivo de la corriente antimanierista en el Perú. Cuando le correspondió ejecutar obras decorativas de mayor envergadura o de contenido narrativo como la Vida de Sunto Domingo Guzmán; Alesio revierte a sus conocimien. tos anteriores y emplea soluciones que corresponden a la contramaniera romana; $y$ en algunos casos, inclusive, utiliza fórmulas más osadas volviendo a esos despliegues de escorzos y anatomías hercúleas con que causó impresión tan profunda en Sevilla (47). Tampoco pudo evitar la tentación de recurrir a algunas alusiones eruditas en sus obras. Al hacerlo, jugó con una de las preferencias de los artistas de la maniera, quienes se complacían con "citas" visuales en contextos incongruentes. Cuando Mateo le otorgó a las rocas del San Cristóbal de Sevilla, el perfil de una de las cabezas de los Gigantes caídos de Giulio Romano (Casa de Te, Mantua) (48) o cuando repitió ese mismo perfil en una de las escenas de los milagros de Santo Domingo, en Lima, el éfecto es más bien el de una referencia culta para sus amigos entendidos, más que ese afón de crear sorpresa, tan caro a los manieristas.

Veinte años menor que los dos anteriores; el tercer artista italiano de quien se conservan obras en América del Sur es Angelino Medoro. Más provinciano $y$ de menos aliento, Medoro siguió un

Es ese cambio el que se refleja en la Virgen de Belén, y no una diferencia de estilo entre Alesio y su mediocre ayudante. Ya Hart-terré (Op. cit., 95) lo señaló claramente: cuando Morón no trabajaba en asociación con Alesio o con Domingo Gil, era conocido como mero "pintor de imaginerí". De modo que atribuir la paternidad de la pintura a Morón es una tesis muy endeble que no agrega nada al conocimiento del arte del siglo XVI. J. MesaciT. Gisbert: WS pintor Mateo Pérez de Alesio. La Paz, 1972, 109-112, 110, n. 67. Véanse los modelos de Pulzone en $\mathbf{F}$. Zeri: $\mathbf{O p}$. cit., figs. 78, 76. Acerca de las réplcas de la Virgen de la leche véase: F. Stastny: Op. cit., 21-24. En relación al cambio de estilo véase nota 24. Acerca del hallazgo de esa pintura, que es la primera obra de Alesio reencontrada en Sudamérica, vease f. Stastny: Op. olt., 8, 10-12.

(47) Hasta qué punto el estilo de Alesio y su adaptación a las mutaciones artísticas de su tiempo pueden eonfundir a estudiosos que no están familiarizados con su obra y con la situación del Cinquecento italiano, se hace evidente en la apresurada monografia de Mesa-Gisbert donde, entre varias otras dudosas atribuciones se publica como de Alesio un conocido dibujo de Francisco Pacheco (EI Juicio de las almas, con falsa firma de Alesio) y en cambio se pone en duda un Padre Eterno, cuyo estilo concuerda perfectamente con el que practicó el maestro en Roma. Véase Mesa-Gisbert, Op. cit., figs. 21 y 22; son igualmente incorrectas las atribuciones de las figs. 1, 2, 3, 4, 15, 24, 27, 28, 32,36 y 39-42. D. Angulo, A. Pérez Sánchez: A Corpus of Spanish Drawings. Londres, 1975, I, 53.

(48) Véase F. Stastny: Pérez de Alesio and the development of Peruvian colonial painting. Tulane University Symposia on the Art of Latin America. New Orleans, April, 1978. 
recorrido que en sus etapas es similar al proceso de Alesio. Ya hemos hecho referencia a su obra sevillana, que se inscribe en-la tendencia del manierismo florentino. Llegado en 1587 a Nueva Granada, su estilo varió radicalmente. Desapareció todo el refinamiento esteticista perceptible en su composición española. Pareciera que Medoro buscara un expresionismo cristiano en la crudeźa de su diseño y en las actitudes exageradas (49). Incluso: antes de llegar a Lima, en 1599, fue sensible a la ola de pintura anti-manierista. Pero en una obra como la Inmaculada Concepción (Fig. 16), en-1618, Medoro trató de superar esas barreras con un mayor volumen y vigor en las figuras. Esta aproximación a soluciones más "barrocas" es tanto más extraña en este caso, cuanto que Medoro partió de un modelo de la contra-maniera. Probablemente el mismo grabado usado por Pulzone en su Inmaculada (Fig. 17) de Ronciglione y del cual existe otra derivación anónima, del siglo XVI, en el Museo de Tepotzotlán.

A diferencia de lo que sucedió en Nueva España, en la Ciudad de los Reyes no se dió una transferencia tan ininterrumpida del estilo pictórico entre maestros y discípulos. Todo lo contrario, la generación siguiente de artistas americanos mostró una fuerte regresión provinciana en relación a los modelos italianos. La diferencia de mentalidad y de clima social y religioso fue tan grande, que se percibe una especie de "mediovalización" en el arte de estos primeros pintores. Dos ejemplos, uno en el Norte y otro en el Sur, serán suficientes para ilustrar esta situación. De Quito viajó a Lima para estudiar en la Universidad en 1576, un joven dominico llamado Fray Pedro Bedón Este aspecto es importante porque señala que fue una persona culta y preparada, en teoría, para asimilar un estilo artístíco que hubiera correspondido a sus necesidades. La única pintura que con certeza se le puede atribuir, que es una variante del tema de la Virgen de la Rosa (Fig. 18), tomada de Alesio, sin embargo, muestra a un pintor que se expresa en un lenguaje plano, anatómicamente inconsistente y que produce primitivas imágenes de piedad (50).

Algo semejante sucedió en el Sur con Gregorio Gamarra. Su estilo, formado en el conocimiento de la abundante obra de Bitti en el Cuzco y el Alto Perú, parece extraer del maestro italiano sólo sus rasgos más gráficos y planos, y tiende a hacer aún más etéreo y alargado el canon de sus figuras (51).

(49) Véase la Parte IV de este trabajo y nota 24. M.S. Soria: Pintores italianos en Sudamérica entre 1575 y 1628, Saggi e Memorie di Storia dell'arte, Venecia, 1965 , No. 4 , 128, fig. 23.

(50) F. Stastny: Op. cit., 1969, 36-41, figs. 1, 14, 15.

(51) Para la relación de Gamarra con Bitti véase: M.S. Soria: La pintura en el Cuzco y en el Alto Perú 1550-1700. AIAA; No. 12, Buenos Aires, 1959, 26, figs. 4-7. 
Mientras tanto, en la tercera década el siglo XVII, en Lima, el estilo italiano continuó floreciendo. Un conjunto mural como la Capilla Villegas (1628), en la iglesia de la Merced, con su abundante decoración grutesca es, en el humor y en el estilo, un producto de la contra-maniera, pero que ha recurrido a considerable uso de estampas ornamentales flamencas para completar sus composiciones (52). En la década siguiente, Leonardo Jaramillo, de origen español, fuertemente imbuído de italianismo, pintó un San Ildefonso (Fig. 19) que no se aparta de la tendencia general, a pesar del alarde del ángel y de la perspectiva arquitectónica, que recuerdan a la tardía maniera florentina, con retraso de medio siglo (53).

Sin embargo desde 1625 empieza a perfilarse en Lima una renovación que implicará el final del italianismo y de la contramaniera. Ântonio Mermejo, fue tal vez un español con formación flamenca. Lo cierto es que sus composiciones denotan paisajes flamencos correctamente estructurados como fondos para figuras religiosas, cuyo vigor y definición psicológica ha superado las ambigüedades de los epígonos manieristas y parecen más bien anticipar un hálito de Rubens (54).

Entretanto en la mayoría de los otros centros se producen, hasta la sétima década y más tarde aún, tardías manifestaciones de contra-maniera con combinaciones híbridas de influencias ítaloflamencas. Un pintor como Acero de la Cruz, en Santa Fe de Bogotá, da un tratamiento gráfico, recortado, a sus figuras que pertenece enteramente al siglo XVI, y en su Inmaculada, de San Francisco, flotan dos angelitos que parecen provenir directamente del pincel de Jan van Hemessen (55). En Quito, en la época de tran-

\section{"Jorge Puccinelli Converso»}

(52) El primero en llamar la atención sobre ese importante conjunto mural fue M.S. Soria: Op. cit., 1959, 322. H. Schenone (1963) y otros repitieron lo dicho por Soria sobre una posible atribución a Pérez de Alesio. El propio Soria en un artículo póstumo (Op. cit., 1965, 128), sin embargo, se corrigió y afirmó acertadamente que las pinturas deben ser del "círculo" de Alesio. Efectivamente en 1628, cuando se pintaron los murales, Alesio había fallecido. Para la aclaración da la fecha de 1628, que fue introducida por un error de imprenta en la biografia de Alesio, véase: F. Stastny: Op. cit., 11, nts. 23 y 24; H. Schenone: Una pintura en Lima atribuída a Pérez de Alesio. AIAA, No. 16, 1963, 28. Tergiversando el texto de Soria. Mesa-Gisbert (Op. cit., 1972, 121) afjrman que la atribución fue "confirmada por Soria en artículo póstumo de 1965".

(53) J. Mesa y T. Gisbert: Op. cit., 1962.

(54) H. Schenone: Notas sobre el arte renacentista de Sucre, Bolivia, AIAA, No. 3, 1950, 59, fig. 15; H. Schenone: Pinturas de las Mónicas de Potosí, Bolivia. AIAA, No. 5, 1952. 55; F. Stastny: Pintores y Catedráticos. U.N.M.S.M. Lima 1975, 7, 20-23.

(55) G. Giraldo Jaramillo: La pintura en Colombia. México, 1948, 42 ss., fig. 2. 
sición al siglo XVIII, Goríbar adopta figuras de Parmigianino (55a). Y en el Alto Perú, Nicolás Chávez de Villafañe pintó, en 1661, imágenes de piedad, con una precisión amanerada que recuerdan al Divino Herrera. En el Cuzco se percibe entretanto con claridad la transformación que se opera debido a la creciente penetración de estampas flamencas, tanto de finales del '500 como de la escuela de Rubens. Es el caso de Quispe Tito y la de un artista mayor de origen español, como Francisco Serrano, quien trabajó en Lima en la década del 40 y veinte años más tarde pintaba en el Cuzco escenas copiadas de grabados de Carel Van Mander (55b).

\section{VI}

Existen dos vertientes claramente marcadas en la pintura de Nueva España en el período que abarca el florecimiento de las corrientes manieristas entre los años 1560 y 1640. Se inició esta etapa con los primeros artistas de personalidad definida llegados de Europa y concluyó con las últimas obras de la siguiente generación: con Echave Ibía, Luis Juárez y López Herrera. A mbas corrientes se inscriben como tradiciones propias $y$ se desarrollan como "transmisiones verticales" muy definidas (56). Una de ellas es plástica, corpórea, táctil; la otra vaporosa, cromática y luminosa. Ambas modalidades se arraigaron tan profundamente en las tradiciones de los obradores novohispanos, que paulatinamente desarrollaron sus raíces en suelos netamente diferenciados: la primera en el retrato y la segunda en la pintura religiosa. Y así perdurarán hasta el final de la época colonial.

Dado el carácter delesa especialización, Ses comprensible que a algunos artistas pueda Situársele exclusivamente en una u otra corriente; mientras que otros se ubicarán sobre la línea de demarcación, con un pie en cada lado, según el género o aún el aspecto de la obra que se juzgue. Con una simetría tal vez demasiado perfecta (Véase el cuadro adjunto), en el primer grupo, Simón Perines, tiene obras que contribuyen desde el inicio a ambas modalidades. Sus paisajes, siguiendo la tradición de Patiner, poseen una

(55a) G. Kubler y M. S. Soria: Op. cit., 320, fig. 175 B; P. Jaramillo Alvarado: Examen critico sobre los Profetas de Goribar. Quito, 1951.

(55b) J. Mesa y T. Gisbert: Historia de la pintura cuzqueña Buenos Aires, 1962, 63 ss., 58, fig. 26. La Huida a Egipto (1663. Iglesia de Tinta, Cuzco) de Serrano es copia fiel de un grabado inventado por C. Van Mander (véase nota 24) y tallado por J. de Gheyn.

(56) El concepto de "transmisiones verticales" tal como lo enunció G. Kubler es algo distinto al uso que se le da acá, ya que se refiere no sólo al desarrollo de una tradición artística local, sino también a su desplazamiento por la escala social desde lo popular a lo oficial o viceversa. G. Kubler: La historia del arte y la historia de las ideas. Museo de Arte y de Historia. UNMSM. Edición mimeográfica. Lima, $1972,3$. 
auténtica procupación por la perspectiva aérea y el fenómeno luminoso. Sus composiciones de figuras religiosas, on cambio, de rivan de la corriente romanista de grandes volúmenes corpóreos. Sus dos sucesores, Echave Orio y Vázquez, pertenecen efectivamente, el uno a la corriente ulástica y el segundo a la tendencia "vaporosa". Distribución semejante se encontrará en la próxima generación. Echave Ibía es plástico y tó́ctil en el tratamiento de sus figuras religiosas $y$ en sus retratos. Pero al mismo tiempo recogió con excepcional habilidad el sentimiento para los fondos de paisaje iniciados por Perines y Vásquez. Poco antes que él, Luis Juárez fue el primero en sintetizar, en base a las enseñanzas de Vázquez, el estilo "vaporoso" de pintura religiosa con rompimientos de gloriu, querubines y ángeles de pasta luminosa, que envuelven las escenas milagrosas sin dejar lugar a otra descripción espacial. Más tarde, Juan Correa y Villalpando llevaron esa modalidad a sus más plenas realizaciones. Mientras que el Divino Herrera, contemporáneo de Ibía y Juárez, desarrolló una obra que está íntegramente dedicada a los valores plásticos, a la descripción del volumen y a una grafía vigorosa. Lo siguió en esa ruta, en el segundo tercio del siglo. José Juárez, artista zurbaranesco.

El reconocimiento de las dos variantes que acabamos de describir es útil en nuestro propósito de asociar los movimientos euro. peos con la pintura novohispana, la cual, dado el consabido re. traso temporal, estuvo desplazada unos 30-40 años en relación a los centros de origen. La tendencia volumétrica o plástica estuvo vinculada a las modalidades más conservadoras del arte europeo, como la anti-maniera romana y flamenca y la contra-maniera de Italia central, movimientos que eventualmente condujeron a un barroquismo de tipo zübaranesco. En cambio, la fase vaporosa ligó la contra-maniera florentina - que fue tan importante en Españacon la influencia indirecta de Barocal (57).

Examinemos brevemente los principales hitos de esta trayectoria. La Virgen del Perdón (1568) (Fig. 8), la obra más antigua atribuída a Simón Perines, refleja nítidamente el apego del artista a soluciones que encuadran en el esquema de la contra-maniera romana en su reutilización de ideas de Rafael (58). Unos veinte años antes, Girolamo Siciolante ensayó exactamente la misma forma de rafaelismo estructurado y clasicista en una pintura como la Madonna con seis santos, de S. Martino Maggiore (Bologna) (Fig. 9), que refleja su intención de alejarse de los excesos de la mamiera

(57) Acerca de la influencia de la pintura florentina en Espania, véase: S. Jacob: Florentinische Elements in der Spanische Malerei des frühen 17. Jahrhunderts, Mitteilungen des Kunsthistorischen Institut in Florenz. Vol. XIII, No. I-II, Diciembre 1967, 115-164.

$35,1966,45$. 
(59). La obra posterior de Pereyns es principalmente una confirmación de esa tendencia o se inclina hacia soluciones propiamente anti-manieristas. Su dependencia de modelos de Martín de Vos, reflejan esa última opción. Vos fue un artista ecléctico que recurrió ocasionalmente, sobre todo en sus dibujos para grabados, a un arcaismo deliberado, como lo hicieron los anti-manieristas romanos. La Circuncisión repetida por Perines en Huejotzingo no es sino un ejercicio en arcaismo intencional que se remonta a las fuentes renacentistas germánicas de Durero (Fig. 20), en vez de apoyarse en Rafael, según la costumbre italiana (60). Menos frecuente en la obra del pintor flamenco es el recurso de una vuelta a sus tradiciones nacionales como modalidad de inspiración anti-manierista. Es el caso del S. Cristóbal conservado en la Catedral.

La tendencia plástica más conservadora fue continuada en Nueva España con la llegada de Echave Orio. En una fecha tan tardía como 1612, Echave produjo un conjunto de obras abiertamente manieristas (61). Es el único caso en México de composiciones derivadas propiamente de la maniera. Es cierto que se trata de composiciones inspiradas en la modalidad del tardío manierismo florentino del cual habian desaparecido las exageraciones extravagantes y que muy pronto conducirá al tipo de reforma contra-manierista practicada por Santi di Tito. Quedan sin embargo las arquitecturas en profundo receso, los personajes en "repoussoir" y la amplitud de gesticulación, característicos de artistas como Il Poppi. Mucho más interesante es en realidad lo que Echave ejecutó en Santiago de Tlatelolco (1609), así como las obras de la Casa Profesa. Se logra en esás pinturas una síntesis muy personal que, en cuanto al contenido transmitido, pertenecen al sentimiento de la anti-maniera por el pudor ylas actitudes piadosas de los personajes; pero cuyo aparato formal combina elementos del naturalismo flamenco con actitudes mucho más avanzadas en la composición de estructura diagonal. Tanto las fórmulas compositivas como el refinamiento del detalle traen a la memoria la obra temprana de

(59) Este estilo de Siciolante fue calificado como: “ . . an almost Nazarene variety of Raphaelism". S.J. Freedberg, Op. cit., 339, fig. 215. (60) La Circuncisión (1585) de Huejotzingo repite fielmente sólo $\overline{4}$ años después de haberse impreso en Amberes (1581) el grabado inventado por M. de Vos y burilado por J. Sadeler; a su vez M. de Vos no hizo sino adaptar una xilografía de A. Durero (c. 1505, Bartsch, 68). No sólo se trata en este caso de un fenómeno de arcaización intencional, sino que para el entendimiento del arte americano a la luz de ejemplos como el que aquí se da, debe distinguirse entre fuentes primarias y fuentes secundarias. Véase sobre este problema: F. Stastny: Durero y la pintura colonial. Simposio B. Roselli, UNMSM. Lima, 1974. Véase también nota 13.

(61) Martirio de San Aproniano, Martirio de San Ponciano y Presentación al Templo (todos en la Pinacoteca Virreinal, México. 
Barocci (62), cuya influencia geográficamente tan dispersa dentro Y fuera de Italia, debió llegarle a Echave por intermedio de las estampas de los manieristas nórdicos tardíos, como Goltzius, Bloemart o Spranger y por consiguiente, desprovista de su calidad pictórica (63).

Frente a Echave, Alonso Vázquez representó una contribución diametralmente opuesta, importante por su concepción luminosa y espacial, tanto en interiores como en el paisaje. La presencia de modelos flamencos grabados o conocidos en vivo, es muy fuerte en su estilo; pero la artificiosidad de esos orígenes está mitigada por su indudable experiencia de fuentes nor-italianas, venecianas y lombardas (64). No hay obras entre las conservadas que se pueden atribuir con certeza a Vázquez en México. Las que se le relacionan señalan su compromiso con soluciones de la contramaniera y revelan la influencia perdurable de los tipos de cabezas rubias y redondas ideados por él. El problemático San Miguel triunfante, está estrechamente vinculado a su estilo por el tipo físico del ángel y el tratamiento luminoso; pero es sin duda del pincel de Juárez. Está basado en el antiguo modelo rafaeliano (repetido por Perino en Sant'Angelo), reinterpretado con influencia de los ángeles de la Capilla Sistina de Alesio, de los cuales Vázquez tuvo conocimiento por los dibujos exhibidos por el italiano en Sevilla, según indica la similitud en el gesto de la mano izquierda (65). Pero lo que es verdaderamente significativo en esa obra es

(62) Parecida evolución hacia Barocci sufrieron varios de los reformistas florentinos. (S.J. Freedberg: Op. cit., 434-5). La fecha es demasiado avanzada (1585-90) para que estas movedades hayan podido ser aprovechadas directamente por Echave, pero una evolución paralela en lugares tan "distantes abundaria en favor de la hipótesis del aprendizaje de Echave en Florencia. Véase notas 14 y 57.

(63) El uso de estampas por Echave Orio y su relación con los movimientos de pintura italo-flamencos, está confirmada por la Epifania (Pinacoteca Virreinal), cuya composición repite al pie de la letra el grabado que sirvió igualmente de modelo al artista flamenco de formación veneciana Roland de Mois (act. 1570-90), en su pintura del Museo de Zaragoza. Compárese las ilustraciones en $M$. Toussaint: Op. cit., fig. 120 y D. Angulo I.: Op cit., 328, fig. 348.

(64) La obra de Vincenzo Campi, por ejemplo, explicaría los logros de Vázquez en el género del bodegón a que se refieren Pacheco y Palomino. El Bodegón (Col. Pastor, Madrid), firmado con un monograma y que Soria atribuyera a Vázquez, parece ser una obra más tardía. D. Angulo I.: Op. cit., 318; M.S. Soria: Notas sobre algunos bodegones españoles del siglo XVI. Archivo Español de Arte, 1959, 275; La peinture Espagnole du Siècle d'Or. Catálogo por A. Pérez Sánchez, Petit Palais, París, 1976, No. 73.

(65) M.S. Soria fue de opinión que ésta era una obra de Vázquez repintada por Juárez (Op. cit., 1959, 307). Después de examinar el original, me parece mucho más convincente la atribución a Juárez, como obra juvenil basada en un original perdido (o un dibujo) de Vázquez. La relación con el ángel del Martirio de Santa Catalina (Catedral de 
la concepción luminosa que envuelve la escena, la cual crea una sensación atmosférica que no sólo anima el paisaje, sino que transforma también a las figuras (66).

En este panorama, Luis Juárez aparece como un importante artista, quien, a pesar de las limitaciones de su formación, logró crear una síntesis propiamente novohispana derivada principalmente del arte luminoso de Vázquez, con algunos aspectos provenientes de Echave. Sin embargo, esos orígenes no explican del todo la pintura de Juárez, en cuyo estilo hay un considerable factor florentino "reformista" en la modalidad de Chimenti da Empoli, ligado a lo que pareciera ser un conocimiento de Barocci. Corresponde a la sensibilidad del artista de Urbino la aleación que se produce en Juárez de factores ópticos y de composición diagonal muy avanzados con una emotividad religiosa todavía vinculada a la antimaniera. ¿Cabe preguntar si el pintor alcanzó ese equilibrio personal tan sólo en base al enfoque atmosférico aprendido con Vázquez y a los modelos manieristas nórdicos usados por Echave, o si efectivamente tuvo un conocimiento más directo de Barocci y de sus sucesores?

Echave Ibía se inscribe al lado de su contemporáneo Juárez, como un artista más tradicionalista y cuya obra aparece escindida entre las dos tendencias que hemos señalado. Pertenecen a la corriente luminosa sus experimentos en el campo del paisaje, que explotan la amplitud de perspectivas panorámicas derivadas de Patinir y de Durero y aprendida en los grabados de Amberes de finales de siglo. Igualmente conservador es su enfoque de la temática religiosa. Obras como sus Inmaculadas (67) o sus retratos pertenecen más claramente a la corriente de la anti-maniera romana. Están elaboradas con cunallminuciosidad exagerada y con un gran despliegue de drapeados volumétricos, parecidos a los de Pulzone da Gaeta, en Italia (68).

Sevilla) señalada por Toussaint es muy evidente. Por otro lado es igualmente notoria la influencia de los modelos de Pérez de Alesio en ambas obras: tanto en la Santa Catalina como en el San Miguel. La primera está muy relacionada a la composición de Alesio grabada por P. Perret en 1582; coinciden el esquema general, asi como las actitudes de los tres soldados que rodean a la santa; mientran que el ángel de la parte superior, tan similar al de México, combina el tórax y el movimiento de brazos del ángel central con las piernas del ángel del lado derecho de la Defensa del cuerpo de Moisés (Capilla Sistina) de Alesio. M. Toussaint: Pintura Colonial en México. México, 1965, 78, fig. 104, 105; C. Le Blanc, III, 169 (en vez de Santa Catalina, registra "Martirio de Santa Lucía"); L.D. Ettlinger: The Sistine Chapel before Michelangelo, Oxford, 1965, 41, fig. 7.

(66) Por otro lado, la medida en que la figura del San Miguel se aleja del ideal de la figura serpentinata indica el compromiso de Vázquez (y de Juárez) con la contra-maniera.

(67) M. Toussaint: Op. cit., figs. $129,130$.

(68) F. Zeri: Op. cit., fig. 15. 
Mucho más cercano aún al espíritu de la anti-maniera y al estilo que propugnaron Valeriano y Pulzone está la obra de López Herrera. Uno de los principales eslabones en la tradición plástica y totalmente opuesto a Juárez, el Divino Herrera experimentó con diversas modalidades de expresión que recurren a la facilidad gráfica desarrollada en la maniera, pero la aplican con cuidadosa simetría y con una claridad compositiva que tienen como primera consideración la transmisión del contenido religioso. Incluso en el vigor de su caracterización anatómica, la Asunción señala hacia su origen en el lindero entre la contra y la anti-maniera (69). Parecido experimento contra-manierista es la Resurrección de Cristo (70). Pero sus obras más numerosas están concebidas como andachtsbilder y se inspiran fuertemente en el "arte sacra" flamenco. La Santa Faz, tantas veces repetida por él, es una típica "imagen de piedad", derivada del tema de La Verónica pintada por Memling y plasmada por Albert Bouts (Museo de Amberes) en la iconografía patética que será empleada más tarde por Herrera (71).

El panorama que predominó en Nueva España hasta el año 1640 fue, por consiguiente, el de una escuela de pintura que desarrolló una variedad de facetas en las cuales, a primera vista, primaron las influencias flamenca y española; pero que, por la naturaleza misma de la pintura europea de la época, estuvo también profundamente impregnada por el arte italiano. En los ochenta años que duró este período las variantes estilísticas que se produjeron oscilaron principalmente entre modalidades de la contramaniera y de la anti-maniera, que condujeron, en una etapa, a experimentos más avanzados de pintura luminosa. En cambio, con excepción de un caso aislado en la obra de Echave Orio, no se dieron expresiones que pudieran llamarse propiamente manieristas.

\section{VII}

El panorama que acabamos de trazar señala claramente la naturaleza de la pintura latinoamericana de este período. Tanto en el

(69) Compárese, por ejemplo, con una obra de humor parecido: La Ascensión (Santi Giacomo e Filippo, Palidoro) de G. Valeriano, pintada poco antes de su ingreso a la Compañía de Jesús. (F. Zeri: Op. cit., fig. 55); y para la posible relación con modelos de Sturmio y Morales: G. Kubler y M.S. Soria. Op. cit., 309.

(70) La figura del Cristo resurrecto es una hábil reelaboración del Cristo de la estampa de igual tema diseñada por M. de Vos (grabada por J. Sadeler), del cual se conserva un ejemplar en el álbum de grabados antiguos de la Biblioteca Nacional de México. Más parecido por la posición elevada de la figura es el cuadro del Triunfo de Cristo (1590) del mismo artista en el Museo de Amberes (No. 72).

(71) Musée Royal des Beaux Arts d'Anvers: Op. cit., fig. 14; M. Toussaint: Op. cit., fig. 110 . 
PINTURA MEXICANA

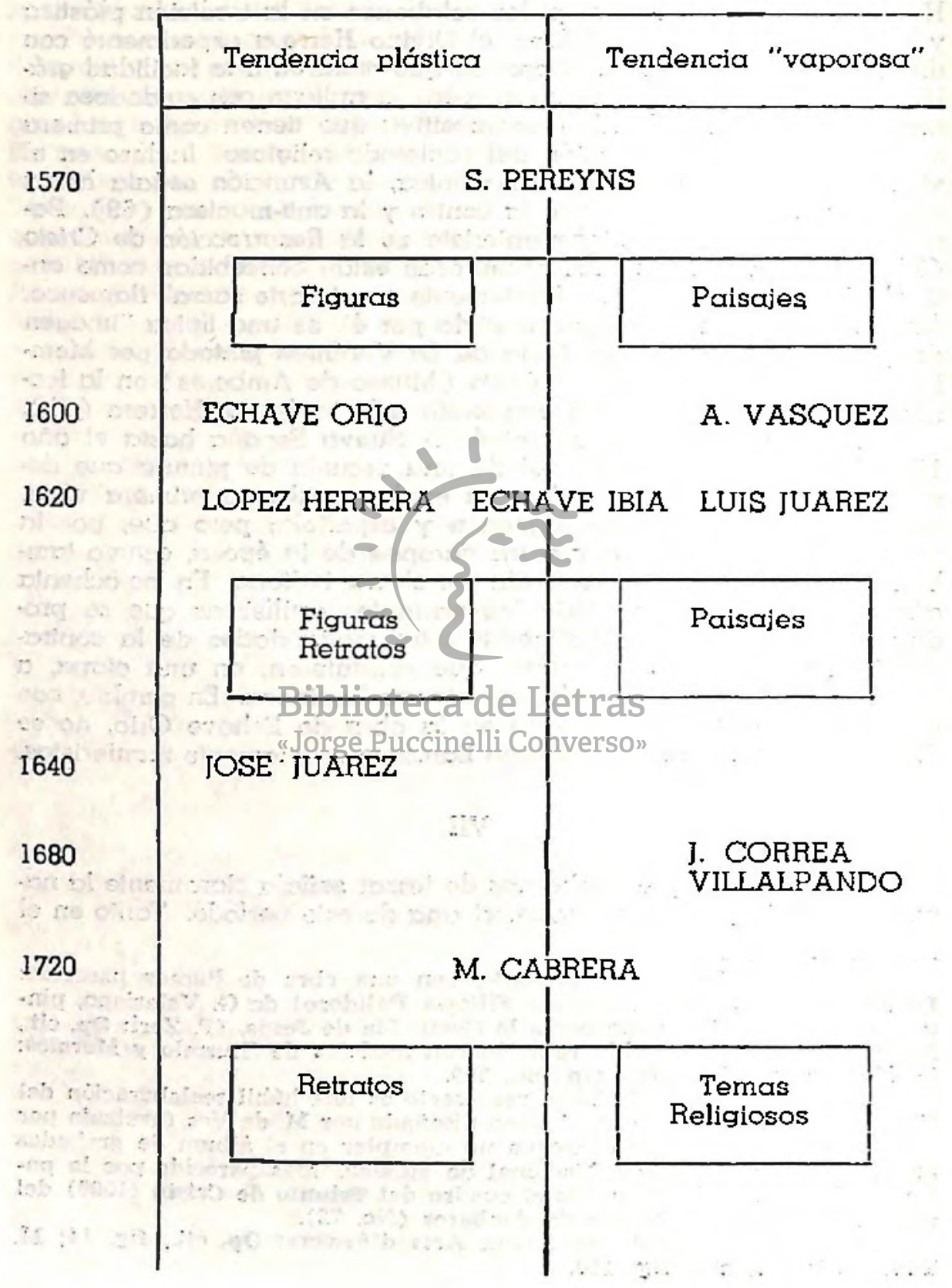


Norte como en el Sur del Continente el punto de partida fue la corriente artística de la contra-maniera. Llegada la última década del siglo, casi simultáneamente con Europa, adviene la modalidad de la anti-maniera que se enlaza con la tendencia anterior. En cambio, el manierismo propiamente dicho, en su forma anti-clásica -según la terminología de Friedländer- está prácticamente ausente del arte americano.

Nada puede puntualizar mejor, a modo de conclusión, esta situación ambivalente que un examen de la actitud de la pintura americana frente a la representación de la figura humana. Los artistas del Nuevo Mundo aceptaron los modelos del arte europeo del siglo XVI selectivamente. Adoptaron favorablemente el canon extremadamente esbelto, que favorecía la expresión de las imágenes idealizadas de su mundo místico y concordaba con su sentimiento de la elegancia cortesana. (Hibridación que es muy semejante a la del gótico tardío). En cambio, rechazaron drásticamente la complejidad de la figura serpentinata, que fue precisamente la conquista artística más sofisticada y característica de la maniera. Ya en 1564 Andrea Gilio protestó en Italia contra la "distorsión inadecuada y fea" de ese género de figuras aplicadas a la representación de santos (72). Muy parecida debe haber sido la reacción estética del hombre americano frente a tales imágenes.

\section{Abreviaturas:}

AIAA $=$ Anales del Instituto de Arte Americano. Universidad de Buenos Aires.

AIIE = Anales del Instituto de Investigaciones Estéticas. Universidad Nacional Autónoma- de Méxicn.

BCIHE = Boletín del Centro de Investigaciones Históricas y Estéticas. Universidad Central de Venezuela, Caracas.

(72) Citado por J. Shearman: Op. cit., 91. 


$$
\text { :-4en }
$$

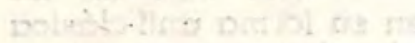

.... nd is tis

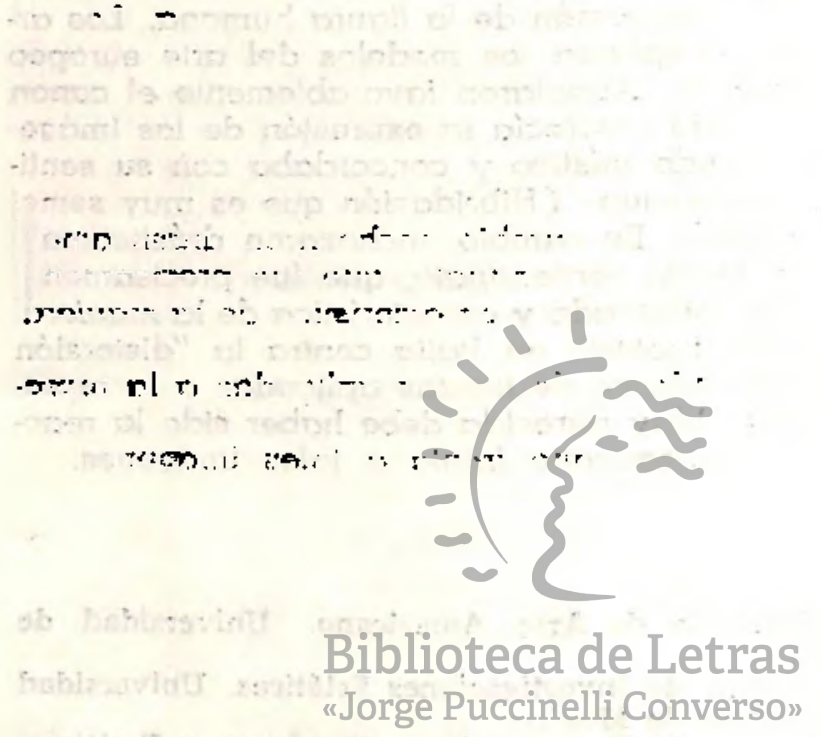

